\title{
Impact of Real Exchange Rate Fluctuations on Aggregate Cocoa and Coffee Exports in Sierra Leone
}

\author{
Pabai Fofanah \\ Central University of Finance and Economics, Beijing, China \\ fofanahpabai@yahoo.com
}

\begin{abstract}
The regression and the vector autoregressive VAR models are employed in this analysis. I use the auto-distributed lag regression model to estimate both the short and long-run impacts. In the VAR model, orthogonalized impulse response functions are employed to estimate the short-run. The regression result shows that while the depreciation of the real exchange rate RER increases aggregate cocoa and coffee exports AGX in the current year, this variable is not significant in determining AGX in Sierra Leone. This is because AGX has a long gestation period and until this period is over; suppliers cannot raise their output and hence exports. The negative effect of the one-period lag of the RER variable on AGX can be attributed to the fact that in the long run, depreciation in the nominal exchange rate leads to real exchange rate depreciation. This will lead to an increase in the cost of imported farming inputs in domestic currency terms. The reduction in imports that follows decreases the output and hence cocoa and coffee exports. However, this variable is not significant in determining AGX in Sierra Leone. An increase in the orthogonalized shock to the first difference of the RER causes a short series of increases in the first differences of AGX followed by a decrease, followed by an increase that dies out after four periods. The null hypothesis that the lag of the first difference of RER does not Granger-cause the lag of the first difference of AGX cannot be rejected. The paper concludes that in the short and long term, the government should not use the depreciation of the real exchange rate as a policy tool to promote the total export of cocoa and coffee products.
\end{abstract}

Keywords: Real exchange rate; trade openness; aggregate cocoa and coffee export; vector autoregressive model; auto-distributed lag regression model.

\section{Introduction}

Sierra Leone is one of the poorest countries in the world. More than $50 \%$ of the government revenue comes from foreign aid and the majority of the population of 7,883,1231 relies on subsistence agriculture and is classed by Food and Agricultural Organization (FAO) as a Low Income Food Deficient Country (LIFDC). On the United Nation's Human Development Index (UNHDI), Sierra Leone was 0.419 points in 2018, leaving it in $184^{\text {th }}$ place in the table of 189 countries $^{2}$. Sierra Leone's economy is strongly reliant on the primary sectors, which are the agricultural and mining sectors. However, despite the country's potential in the mining sector (for example, iron ore, diamond, rutile, and oil reserves), with declining international commodity prices, especially in iron ore (see figure $1 \mathrm{pp} 2$ ) which was one of the country's main exports, agriculture, including forestry and fisheries, is one of the diversified sectors the government is focusing its growth potential. This sector accounts for the largest Gross Domestic Product (GDP) share. The share has increased from its lowest from 29 percent in 1981 to an estimated 60 percent in 2017 (see figure 2 and table 1, pp 2 and pp 3 respectively). Currency depreciation operates in a way that either increases the domestic price or reduces the foreign currency price of exports. It generates an incentive which tends to increase the demand for export goods. It is important to note that depreciation of RER will tend to increase agricultural supply from the transfer of productive resources from the import-substituting and the non traded good sector of the economy. The sector is also the primary source of employment for the majority (60-70\%) of the population ${ }^{3}$. And also contributes to the generation of foreign exchange needed to service foreign debt and other bills. Smallholder farmers dominate the sector and are engaging in subsistence and traditional methods of farming, using limited farming inputs. There are fairly large agricultural estates, both government and privately owned. The government is investing heavily in the sector by improving transport infrastructure to ease the movement of goods, encouraging and supporting private sector investment, as well as lending support to farmers.

\footnotetext{
${ }^{1}$ See population by country; (www.worldometers.info)

${ }^{2}$ See Sierra Leone economy.com 2019 report.

${ }^{3}$ Review of ongoing agricultural development effort. pp1 (www.resakss.org)
} 


\begin{tabular}{l} 
Journal of Economics and Behavioral Studies (ISSN: 2220-6140) \\
Vol. 12, No. 2, pp. 34-56, April 2020 \\
\hline \hline
\end{tabular}

Figure 1: World Price of Iron Ore

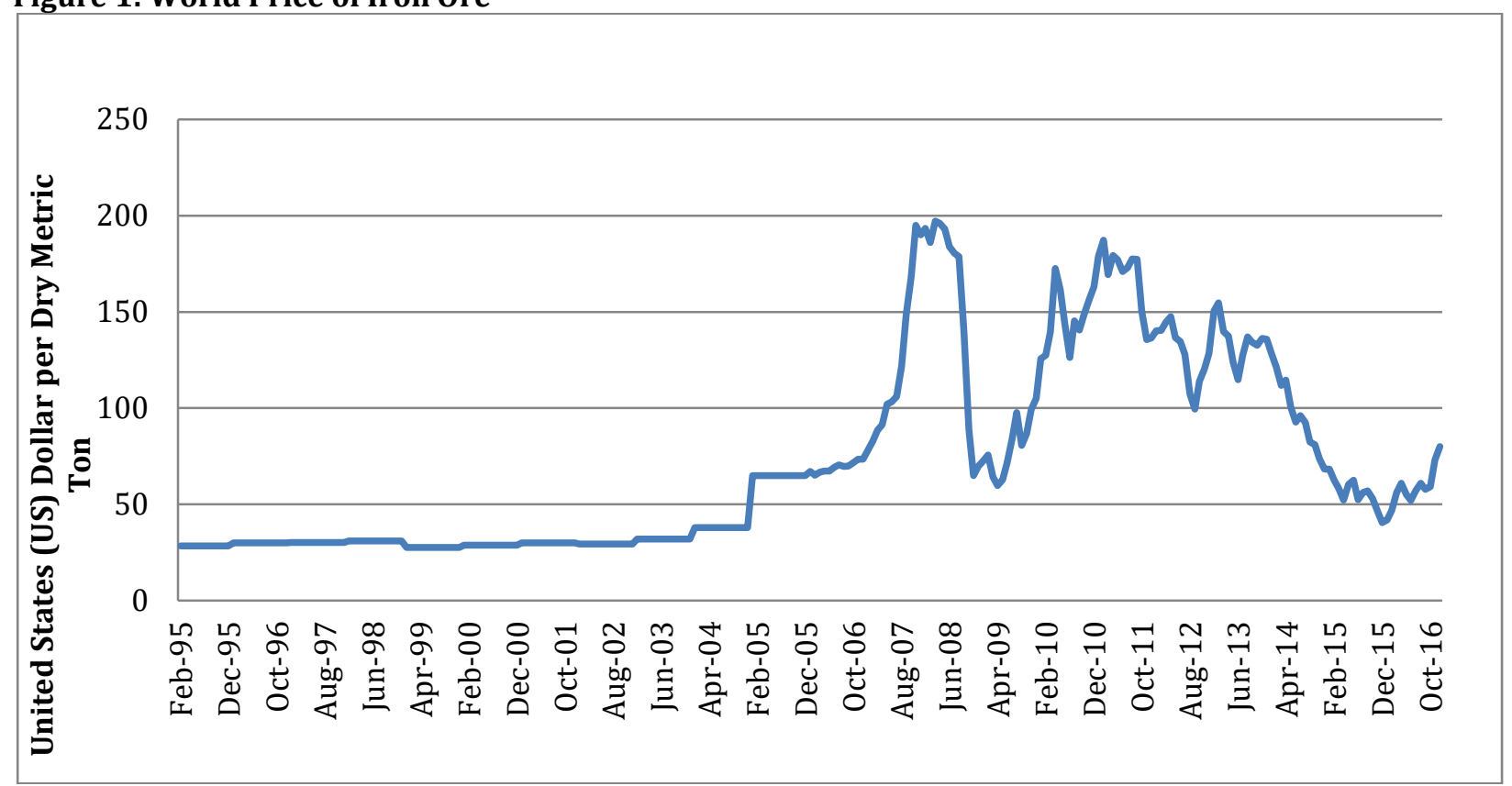

Source: Thomson Reuters Data Stream, World Bank

Figure 2: Share of Agriculture, Including Forestry and Fisheries in GDP

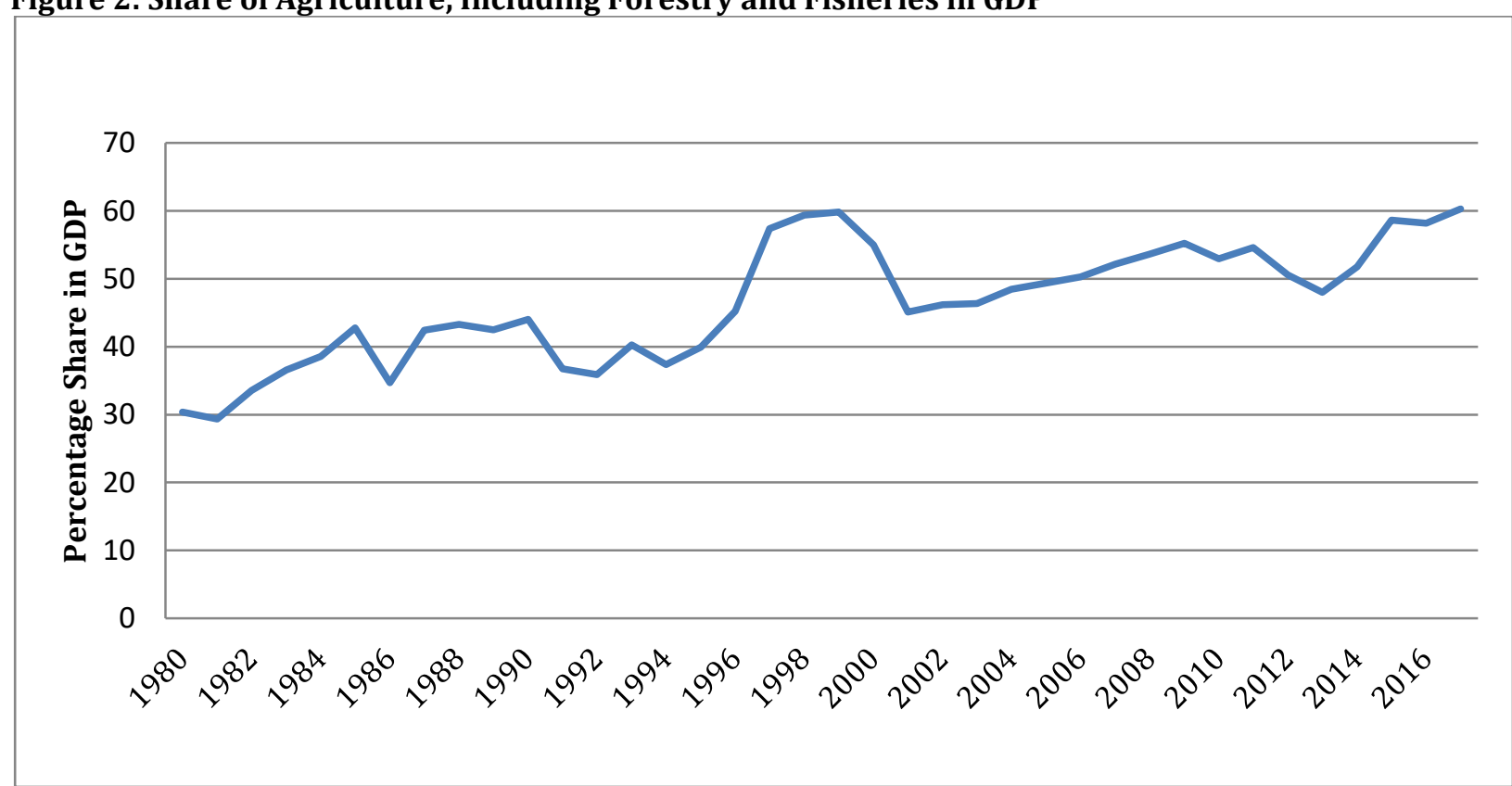

Source: World Bank Data Stream

Historically, the focus of agricultural policies in the country is on the achievement of higher export earnings on major crops like cocoa, coffee, and palm kernel. As such, cooperatives were formed in 1939 to improve the productive capacity of the farmers and also help them get better value for their produce 4 . These cooperatives were under the control of government officials, but they could not, however, control the day to day activities of the farmers. The lack of coordination between the farmers and the government officials coupled with corruption and financial difficulties led to the closure of the cooperatives. Continuous support of the

${ }^{4}$ Review of past agricultural policies in Sierra Leone. pp17 - 19, (www.fao.org) 
production of cash crops by the government led to the formation of the Sierra Leone Produce Marketing Board (SLPMB) in 1949 as the sole legal entity responsible for the purchase, promote growth and stabilize the price of export, and marketing of the country's agricultural cash crop products (cocoa, coffee, palm kernel, piassava, and ginger). This Monopoly has caused severe distortions in the prices of cash crop products, thereby hindering production. However, the continual drive to increase the output of export crops led the government to implement the Structural Adjustment Program (SAP) in 1986, and a subsequent introduction of a floating exchange rate system in which the prices of cash crop products were set at a level equal to the world market prices to provide an incentive to farmers. However, agricultural exports still perform poorly, characterized by large fluctuations in cocoa and coffee exports (see figure 3 below).

\section{Figure 3: Percentage Growth Rate Trend of AGX}

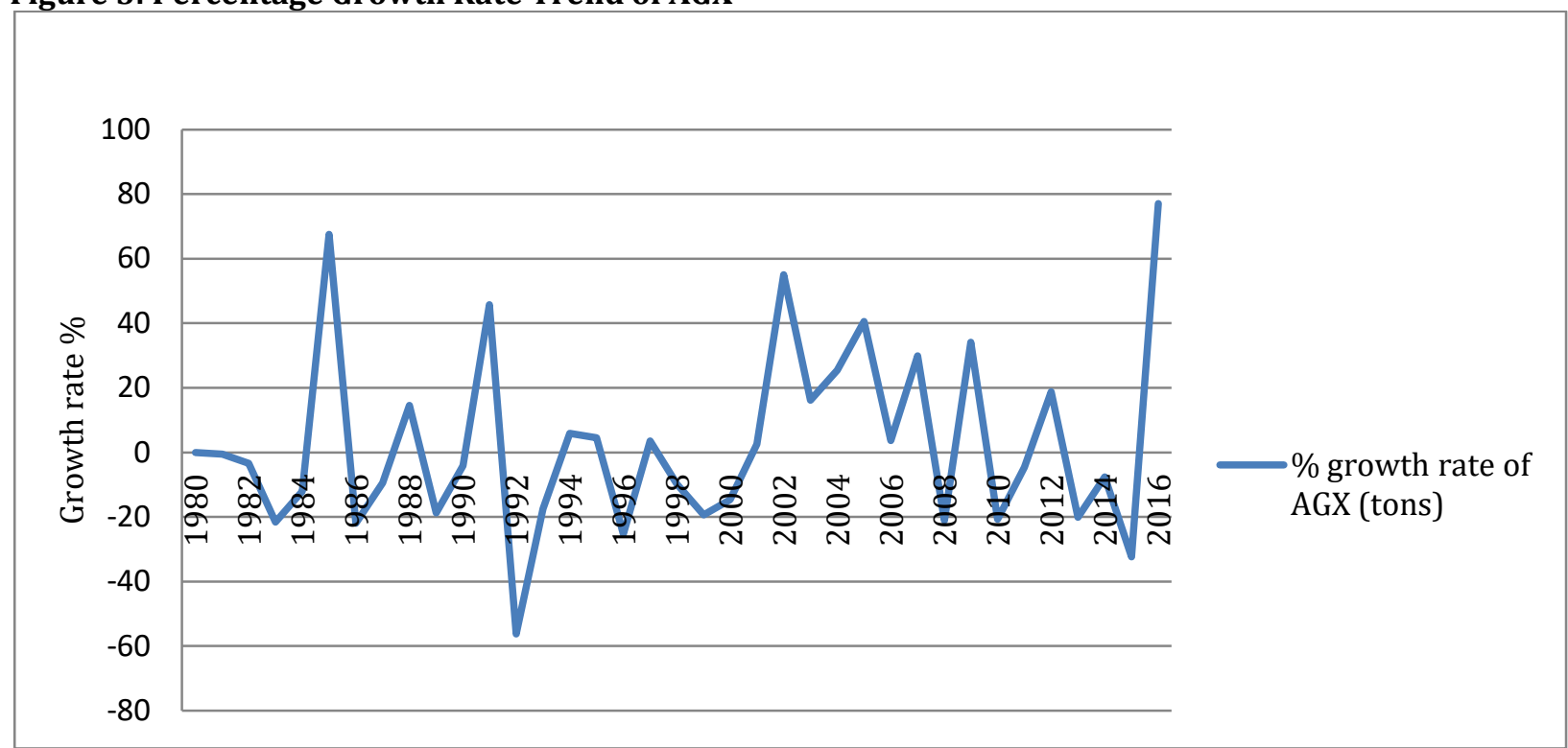

Source: FAO Data Stream

In order to attract a positive response from the agricultural sector, market liberalization reforms have been implemented to ensure that the private sector participates in agricultural export sales. Thus, private sector companies participated in the buying and exporting of produce. They offered better service to farmers than the Sierra Leone Produce Marketing Board through price premiums, pre-financing, and barter systems that provided essential goods in exchange for produce (for more details see Review of past Agricultural Policies in Sierra Leone, www.fao.org). The liberalization policy contributed significantly to the stimulation of cocoa and coffee exports in the late 1980s and early 90s. For example, total exports of cocoa and coffee grew from $18.78 \%$ in 1989 to $45.74 \%$ in 1991 (see table1 below).

Table 1: Percentage Growth Rate in Total Tones, Values of Cocoa and Coffee Exports, and Share of Agriculture Value Including Forestry and Fisheries in GDP

\begin{tabular}{llllll}
\hline & $\begin{array}{l}\text { *Aggregate } \\
\text { cocoa and } \\
\text { coffee } \\
\text { exports AGX } \\
\text { (tons) }\end{array}$ & $\begin{array}{l}\text { *Percentage } \\
\text { growth rate of } \\
\text { AGX (tons) }\end{array}$ & $\begin{array}{l}\text { *Total export } \\
\text { value of cocoa } \\
\text { COX and coffee } \\
\text { CFX (1000 US\$) }\end{array}$ & $\begin{array}{l}\text { *Percentage } \\
\text { growth rate in } \\
\text { the total value } \\
\text { of COX and CFX }\end{array}$ & $\begin{array}{l}\text { *Share of Agriculture } \\
\text { value including } \\
\text { Forestry and Fisheries } \\
\text { in GDP }\end{array}$ \\
\hline 1980 & 18406 & - & 50630 & & 30.376 \\
1981 & 18314 & -8.234 & 30644 & -39.475 & 29.330 \\
1982 & 17701 & 26.279 & 29161 & -4.839 & 33.593 \\
1983 & 13877 & 12.574 & 23562 & -19.200 & 36.565 \\
1984 & 12213 & -11.807 & 27590 & 17.095 & 38.578
\end{tabular}




\begin{tabular}{|c|c|c|c|c|c|}
\hline \multicolumn{6}{|c|}{$\begin{array}{c}\text { Journal of Economics and Behavioral Studies (ISSN: 2220-6140) } \\
\text { Vol. 12, No. 2, pp. 34-56, April } 2020\end{array}$} \\
\hline 1985 & 20461 & 6.990 & 49131 & 78.075 & 42.793 \\
\hline 1986 & 15969 & 4.256 & 42983 & -12.513 & 34.730 \\
\hline 1987 & 14460 & -42.427 & 38205 & -11.116 & 42.463 \\
\hline 1988 & 16557 & 2.764 & 26464 & -30.732 & 43.313 \\
\hline 1989 & 13448 & $\begin{array}{l}7.087 \\
-1309\end{array}$ & $\begin{array}{l}17165 \\
14495\end{array}$ & $\begin{array}{l}-35.138 \\
-15555\end{array}$ & $\begin{array}{l}42.509 \\
44029\end{array}$ \\
\hline 1990 & 12900 & -1.309 & 14495 & -15.555 & 44.029 \\
\hline 1991 & 18800 & -24.741 & 18900 & 30.390 & 36.745 \\
\hline 1992 & 8223 & -9.617 & 6782 & -64.116 & 35.887 \\
\hline 1993 & 6780 & -5.103 & 6216 & -8.346 & 40.302 \\
\hline 1994 & 7178 & -11.269 & 8639 & 38.980 & 37.395 \\
\hline 1995 & 7500 & -2.681 & 12900 & 49.323 & 39.955 \\
\hline 1996 & 5600 & -1.672 & 7600 & -41.085 & 45.210 \\
\hline 1997 & 5800 & 52.882 & 10500 & 38.158 & 57.396 \\
\hline 1998 & 5230 & -11.683 & 8200 & -21.905 & 59.402 \\
\hline 1999 & 4220 & 19.957 & 5350 & -34.756 & 59.866 \\
\hline 2000 & 3600 & 1.746 & 3700 & -30.841 & 55.014 \\
\hline 2001 & 3690 & -19.402 & 4287 & 15.865 & 45.136 \\
\hline 2002 & 5722 & 6.275 & 5206 & 21.437 & 46.214 \\
\hline 2003 & 6646 & -1.341 & 9402 & 80.599 & 46.357 \\
\hline 2004 & 8337 & -0.090 & 11020 & 17.209 & 48.486 \\
\hline 2005 & 11722 & 7.598 & 14625 & 32.713 & 49.391 \\
\hline 2006 & 12146 & 3.918 & 15416 & 5.409 & 50.294 \\
\hline 2007 & 15774 & 1.479 & 23679 & 53.600 & 52.176 \\
\hline 2008 & 12453 & 9.150 & 25164 & 6.271 & 53.654 \\
\hline 2009 & 16697 & 20.960 & 31755 & 26.192 & 55.261 \\
\hline 2010 & 13235 & 0.578 & 30979 & -2.444 & 52.943 \\
\hline 2011 & 12621 & 3.880 & 32576 & 5.155 & 54.593 \\
\hline 2012 & 14982 & -5.476 & 36748 & 12.807 & 50.592 \\
\hline 2013 & 11966 & -14.255 & 25196 & -31.436 & 47.983 \\
\hline 2014 & 11057 & 16.423 & 29704 & 17.892 & 51.793 \\
\hline 2015 & 7487 & 18.411 & 18114 & -39.018 & 58.652 \\
\hline 2016 & 13252 & 9.193 & 34294 & 89.323 & 58.209 \\
\hline 2017 & & & & & 60.284 \\
\hline
\end{tabular}

Source: FAO and World Bank Data Stream

Note: *Author's calculation

However, the lack of stable prices for cocoa and coffee exports and the abandonment of quality control are the limiting factors for continued expansion. Also, the intensification of the civil war since 1991 severely affected cocoa and coffee exports as thousands of farmers fled their farms and homes, this event puts the total cocoa and coffee exports from 18,800 tons in 1991 to 3,600 tons in 2000 (see table 1 above). After the cessation of the civil war, and subsequent investment by the government and external donors in the agricultural sector, the total tones of cocoa and coffee exports increased, but showed persistent fluctuations and declining growth rate trends from 2002 with the exception of 2016 (see figure 3 and table 1). Correspondingly, the total value of cocoa and coffee exports also showed continued fluctuations and downward trends, except for 2016. For example, the growth rate of the total value of cocoa and coffee exports showed $80.60 \%$ in 2003. This trend dropped to $-39.02 \%$ in 2015 (see figure 4 below and table 1 above). 


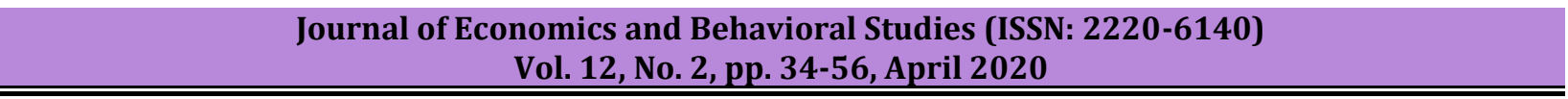

Figure 4: Percentage Growth Rate of Total Value of COX and CFX

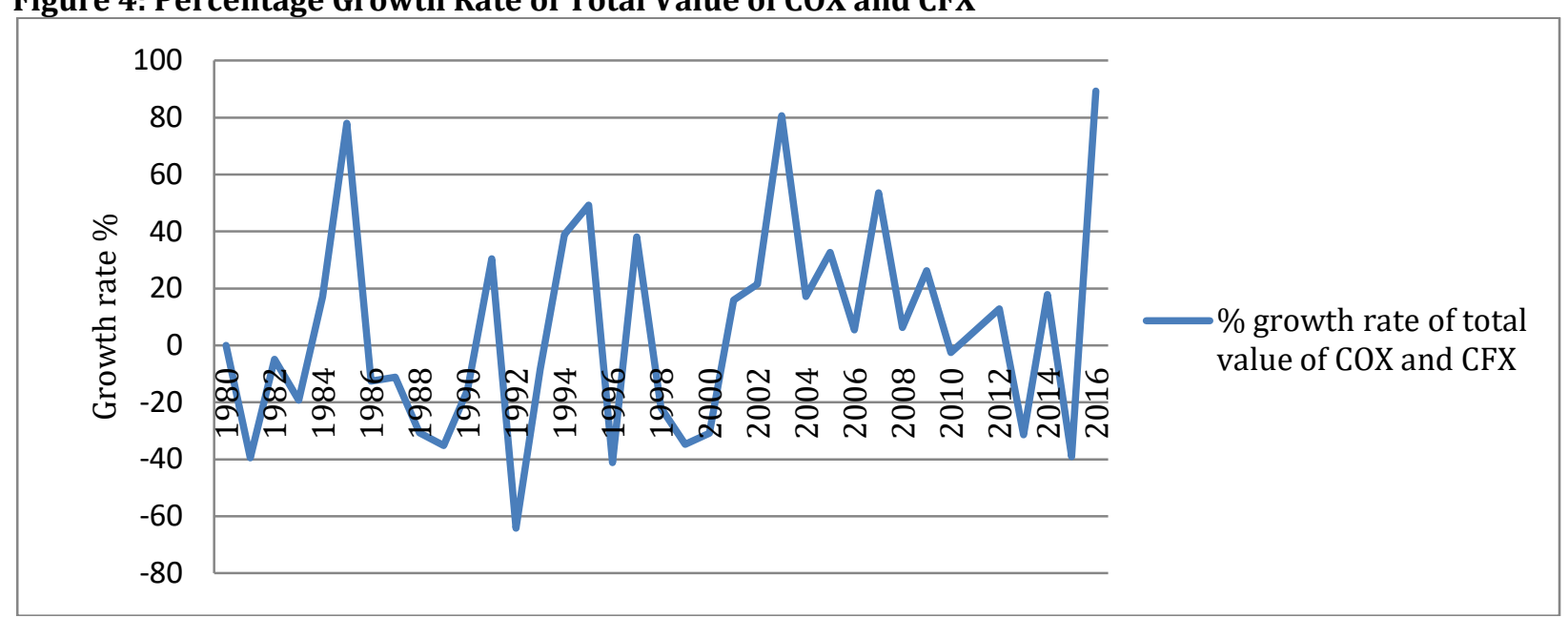

Source: FAO Data Stream

Research Problem: The empirical literature suggests that the exchange rate fluctuation is likely to be a major factor influencing exports decline (see Zafar and Ahmad (2011); Sandu and Ghiba (2011); Tarawalie et al. (2013); Serenis and Tsounis (2014); Srinivasan and Kalaivani (2013); Bahmani-0skooee and Gelan (2018); Khalighi and Fadaei (2017); Betten and Belongia (1984) and many more). However, little information is available about the extent to which this conclusion may be true for Sierra Leone in the case of aggregate cocoa and coffee exports and because the supply of cocoa and coffee is inelastic and depends on the weather condition.

Research Questions: The review of some relevant pieces of literature on this field of study, aid the development of the research questions, (hereinafter, RQ). Consequently, the two questions are thus: RQ1: What is the short-run impact of real exchange rate fluctuations on aggregate cocoa and coffee exports in Sierra Leone? RQ2: What is the long-run impact of real exchange rate fluctuations on aggregate cocoa and coffee exports in Sierra Leone?

Research Aim and Objectives: This paper aims to investigate the impact of fluctuations in the real exchange rate on aggregate cocoa and coffee exports in Sierra Leone for prudent policy implication. To achieve the aim, the research presents three objectives with the research questions acting as a foundation, and these objectives are:

(A) To investigate the short-run impact of real exchange rate fluctuations on aggregate cocoa and coffee exports in Sierra Leone.

(B) To investigate the long-run impacts of real exchange rate variation on aggregate cocoa and coffee exports in Sierra Leone.

(C) Propose policies to improve the production and export of cocoa and coffee in Sierra Leone.

Research Hypothesis: The research tests the following hypothesis:

$\mathbf{H}_{\mathbf{0}}$ : Real exchange rate variations have a significant impact on aggregate cocoa and coffee exports in the short run in Sierra Leone.

$\mathbf{H}_{1}$ : Real exchange rate variation does not have a significant impact on aggregate cocoa and coffee exports in the short run in Sierra Leone.

$\mathbf{H}_{\mathbf{0}}$ : Real exchange rate variations have a significant impact on aggregate cocoa and coffee exports in the longrun in Sierra Leone.

$\mathbf{H}_{\mathbf{1}}$ : Real exchange rate variation does not have a significant impact on aggregate cocoa and coffee exports in the long-run in Sierra Leone.

Significance of the Study and Outline: This paper disaggregates Sierra Leone's trade with the rest of the world, by sector and by-product, and considers the impact of real exchange rate variation on cocoa and coffee exports. Thus, this study would serve as a good guide to the government and private sector in realizing the 
impact of fluctuations in the real exchange rate on aggregate cocoa and coffee exports in Sierra Leone. It will also be of great help to students and researchers in related fields as it would widen and improve their knowledge of the sector and on cocoa and coffee products in particular. The remainder of this research is as follows: Section 2, the literature review. The third section is the model specification, the scope and source of data and methodology. Section 4, the result presentation, and interpretation. Section 5 presents conclusions and policy recommendations.

\section{Literature Review}

This section discusses the extent and related literature, including theoretical and empirical review of past works by different writers and researchers on the exchange rate, trade, agricultural exports, and related field of study.

Theoretical Review: Economists normally agree that changes in the exchange rate can either be nominal or real (Betten and Belongia 1984). The nominal exchange rate is the relative price of the currencies of two countries. These rates are observable and are a result of the market and other forces out of our control (Kristinek and Anderson, 2002). For example, if the exchange rate is $\$ 1=S L L 10$, it means the exchange rate of one United States Dollar (USD) is ten Sierra Leone Leones (SLL) in the world market. Correspondingly, Sierra Leoneans can exchange ten Leons for one US dollar. Edwards (1989), opined that in an inflationary world, changes in the nominal exchange rate would have no clear meaning and that researchers should give consideration to changing values in the domestic and foreign currencies, as measured by the rates of inflation. In this context, the central focus of any international transaction is the real exchange rate. The real exchange rate involves adjusting to a specify nominal exchange rate for relative inflation between a domestic economy, and the rest of the world to determine the effect on incentives to produce, purchase and store commodities and services (Snape 1988; Kristinek and Anderson, 2002). The concept is a measure of the degree of competitiveness of a country in the international market. Expressed as RER $=e^{*} \mathrm{P}_{\mathrm{f}} / \mathrm{P}_{\mathrm{d}}$.

Where: RER = real exchange rate

$\mathrm{e}=$ nominal exchange rate

$\mathrm{P}_{\mathrm{f}}=$ foreign price level

$\mathrm{P}_{\mathrm{d}}=$ domestic price level

Theoretically, when the exchange rate appreciates, foreign goods become cheaper in the domestic market and there is downward pressure on domestic prices. In contrast, the prices of domestic goods paid by foreigners go up, which tends to decrease foreign demand for domestic products. Thus, the exchange rate appreciation tends to reduce exports, and if there is no corresponding change in the relative prices in the rest of the world, the appreciation of the exchange rate would represent a decrease of the country's competitiveness in the international market (Tarawalie et al., 2012; Jiang 2014). Exchange rate depreciation has the opposite effect. It tends to improve the competitiveness of domestic goods in foreign markets while making foreign goods less competitive in the domestic market by becoming more expensive, this event transmits to higher exports and lower imports (Tarawalie et al., 2012). If the domestic currency depreciates, exports become cheaper due to the change in relative prices. However, the effect of depreciation depends on the elasticity of demand for exports and imports (Cao-Alvira 2014). The experience with the Structural Adjustment Programs (SAP) in developing countries seems to suggest the important facts in the failure of a depreciation in the exchange rate to increase exports is the inability of the authorities to ensure that the exchange rate falls significantly and remains at its depreciated rate for a period long enough to permit adjustment supply.

Invariably, this is due to the failure by the authorities to pass on price increases to exporters where there is price regulation. Furthermore, lags in recognition of the changed situation lag in the decision to change variables, lag in delivery time, lags in replacement of inventories and materials, and lags in production. These lags ensure that the demand for exports remains inelastic in the short term. In the long run, when prices become flexible, there will be a positive quantity effect because domestic consumers tend to buy fewer imported goods and foreign consumers tend to buy more exported goods. A fundamental issue facing the exchange rate is whether a country's RER is out of line to its long-run equilibrium level. It is a general belief that maintaining the RER at the wrong level will generate welfare costs because it will often produce 
incorrect signals to economic agents and lead to greater economic instability. According to Edwards (1989), the immediate determinants of the equilibrium RER are the fundamentals. Therefore, at any point in time, RER behavior depends on the value of fundamentals and macroeconomic pressures, such as excessive money supply and fiscal deficits. Orden (2002) pointed out that exchange rate changes depend on international capital flows, and macroeconomic factors determine these flows, including monetary policy. These structural policy implications of exchange rate movements, along with their direct effects on markets at any given moment in time, are why exchange rate movement is important to agriculture.

Empirical Review: The literature has shown many pieces of researchers investigating the impact of the exchange rate on export trade. According to Edwards (1989), there are no indications that higher variability in the real exchange rate affects the level of exports. However, the study by Serenis and Tsounis (2014) found significant negative effects from the volatility of the exchange rate on exports for the countries in their sample when using a measure of unexpected fluctuation. The empirical analysis of Serenis and Tsounis (2013) suggests that exchange rate volatility when measured as the sample standard deviation of the log effective exchange, does not affect the level of exports for both Croatia and Cyprus. However, using an alternative measure there is an indication of a stronger effect from movements of the exchange rate to the level of exports. Consequently, the results show a negative statistically significant relationship for Croatia. This result implies that different measurements in the exchange rate have different implications for exports. Serenis and Tsounis (2012) use three different volatility measures. The empirical analysis suggests that exchange rate volatility when measured as the sample standard deviation of the log effective exchange has a small effect on the level of exports for the sample European Union (EU) countries. However, using alternative measures that capture the effects on high and low values of the exchange rate, there is an indication of a stronger effect from movements of the exchange rate to the level of exports. Consequently, their findings suggest a significant statistical relationship that displays negative effects between sectoral exports and exchange rate volatility. This result confirms the view that different exchange rate measurements have different implications for exports. The empirical findings of Zafar and Ahmad (2011), apply a fixed-effects model to find out the impact of exchange rate volatility on export growth of 16 Latin American countries. The study finds a significant negative effect of exchange rate volatility on export growth. This finding is consistent with the findings of many earlier studies confirming a negative relationship between exchange rate and export. Equally, Srinivasan and Kalaivani (2013) empirically investigate the impact of exchange rate volatility on the real exports in India using the Autoregressive Distributed Lag (ARDL) bounds testing procedure. Their findings suggest that the exchange rate volatility has a significant negative impact on real exports both in the shortrun and long-run, implying that higher exchange rate fluctuation tends to reduce real exports in India. This study also confirms the negative relationship between exchange rate volatility and exports.

According to Tarawalie et al. (2013) in their study, "The relationship between exchange-rate volatility and export performance in the West African Monetary Zone (WAMZ) countries," using quarterly data. Their results suggest that increases in the exchange-rate volatility exert a significant negative effect on exports in Liberia, Nigeria, and Sierra Leone. While the result shows a positive relationship in the case of The Gambia, exchange-rate volatility impact on Ghana and Guinea is insignificant. Their study also finds that the real effective exchange rate hurts export performance in the case of The Gambia, Ghana, and Nigeria. Their results also show a positive relationship in the case of Guinea and Liberia. However, although the long-run result indicates a positive relationship for Sierra Leone, its impact in the short run is negative. Correspondingly, Bahmani-Oskooee and Gelan (2018) investigate a sample of twelve African countries to distinguish the impact of the real exchange-rate volatility on their exports and imports, both in the short-run and long-run, using the bounds-testing approach. The short-run impact of the real exchange-rate volatility either worsens or improves exports in eight out of twelve African countries. The list includes Egypt, Ethiopia, Lesotho, Mauritius, Morocco, Nigeria, Sierra Leone, and South Africa. However, short-run effects lasted into long-run negative effects in Nigeria and Sierra Leone, and positive effects in Egypt, Ethiopia, and Lesotho. Furthermore, the findings suggest that currency depreciation stimulates exports of Egypt, Lesotho, and Nigeria but hurt exports of Ethiopia and Sierra Leon. The negative sign of depreciation in the exchange rate on the export of Ethiopia and Sierra Leone implies that an increase in the exchange rate harms exports of the two countries.

In their paper, Sandu and Ghiba (2011) analyze the exchange rate influence on export volume in Romania using a vector autoregressive (VAR) model. Their analysis, vis-à-vis the 2003 quarter two to 2011 quarter one 
period, reflects a negative relationship for the first lag and a positive one in the second lag. Considering the importance of the first lag, the increase in the exchange rate has an impact on the reduction in exports. Also, according to the impulse-response function, a shock in the exchange rate has significant effects on exports after two periods. On the other hand, Bouoiyour and Selmi (2013) make use of meta-analysis in an attempt to answer the question, whether exchange rate uncertainty affects export performance? The total sample of 56 studies from 1984 to 2013 provides stronger support for the link between risk aversion and hedging instruments, which is a conflicting relationship between exchange rate fluctuations and exports that are generally expected in theory. Using subgroup meta-analysis to provide further evidence on the results already obtained by decomposing their sample into four subgroups depending on the nature of countries, and the models explored to determine volatilities, the evidence from subgroups is not supportive of this association. Caglayan and Di (2010) empirically studied the impact of real exchange rate fluctuations on the sectoral bilateral trade flows between the United States and its top 13 trading partners. They provide evidence that exchange rate volatility does not systematically affect sectoral trade flows. On the other hand, Huchet-Bourdon, and Korinek (2011) examine the impact of exchange rates and their volatility on trade flows in China, the Euro area and the United States in two broadly defined sectors, agriculture on the one hand and manufacturing and mining on the other. The study finds that exchange rate volatility impacts trade flows only slightly. Exchange rate levels, on the other hand, affect trade in both agriculture and manufacturing and mining sectors, but do not explain all the trade imbalances in the three countries examined. Another study that examines the question of exchange rate effects on agriculture comes from Orden (2002). The study shows that exchange rate movements determine the wedge between the domestic and foreign prices of a traded good. And those monetary shocks have non-neutral effects that explain some of the variability in agricultural prices. Khalighi and Fadaei (2017) study the impact of exchange rate on date export in Iran from 1991-2011. Applying the ordinary least squares (OLS) method in the estimation, the results suggest that the exchange rate is a crucial factor for date export and also for exporters. The results also show that the implementation of a unified exchange rate policy without the appropriate exchange rate to encourage exporters would harm date exports. In Shane et al. (2008), their paper estimates the trade-weighted exchange rate and trade partner income effects on U.S. agricultural exports. For the period 1970-2006, the results suggest that a one percent annual increase in trade partners' income increase total agricultural exports by about $0.75 \%$, while a $1 \%$ appreciation of the dollar vis-à-vis trade partner trade-weighted currencies decreases total agricultural exports by about 0.5\%. The empirical results of Wondemu and Potts (2016) suggest that while overvaluation is harmful to exports, undervaluation of the real exchange rate boosts export supply as well as export diversification. The high growth rate of exports is related to the period when the currency is undervalued. However, an export expansion achieved through undervaluation raises the rate of inflation for Tanzania. Uduh (2017) examined the impact of the exchange rate on cocoa export in Nigeria.

Employing the Augmented Dickey-Fuller Unit root, Johansen cointegration, ordinary least square, and diagnostic tests, as well as error correction mechanisms to analyze the secondary time series data. The t-test showed a direct relationship between cocoa export and exchange rate, but an inverse relationship with trade openness and world cocoa price. In general, the paper concludes that agricultural exports, exchange rate, trade openness, and the world price of cocoa taken together affect cocoa export in Nigeria. The findings of Fosu (1992) show that the effect of the real exchange rate on the domestic aggregate agricultural to nonagricultural price ratio is statistically significant at the $10 \%$ level. The result further shows that nominal exchange rate changes influence public policy regarding the pricing of cocoa, coffee, and shea nuts. Also, the study suggests that the decline in the agricultural exports of cocoa and coffee, and the share of exports in the value of real agricultural output during the period 1960-87 is due to the appreciation of the real exchange rate. Furthermore, the study shows that the response of agricultural exports to a change in the real exchange rate is inelastic; suggesting that a large change requires to stimulate the desired increases in agricultural exports. Snape (1988) opined that the appreciation of the real exchange rate made it more difficult for U.S. farmers to compete with foreigners in the export as well as domestic markets. In countries where the real exchange rate appreciates against the US dollar, unless agriculture also requires a lot of capital, agriculture can more easily compete with US producers. The empirical result of Hossain (2018) shows that the depreciation of Bangladeshi currency maximizes agricultural exports and encourages producers to produce more agricultural products. Betten and Belongia (1984) in their paper "The recent decline in Agricultural Exports: Is the exchange rate the culprit?" Empirical evidence on factors affecting U.S. agricultural exports suggests a negative relationship between real exchange rates and exports. Overall, their analysis shows that 
foreign income and not real exchange rate is the most primary determinants of U.S. agricultural exports. Correspondingly, Akinniran and Olatunji (2018) employed the unit root test and regression analysis to evaluate the trend in agricultural exports, examine the effect of the Structural Adjustment Program (SAP) in agricultural exports and investigate the determinants of agricultural exports in Nigeria. The results show that the lag values of exchange rate devaluation have a significant and positive relationship with agricultural exports. The results also show that the exchange rate devaluation in the SAP, and the pre SAP eras has no significant effect on agricultural exports except in the case of natural rubber exports. Furthermore, the results also suggest that per capita agricultural gross domestic product in Naira has a significant negative relationship with total agricultural export commodities. The results of the analysis suggest that agricultural export in Nigeria does depend on the exchange rate and the price of crude oil in the long run. In general, the literature has received mixed empirical support. Some have suggested that exchange rate volatility does depress the level of exports, whilst others suggested positive and some insignificant effects. However, little information is available about the extent to which these conclusions may be true for Sierra Leone in the case of cocoa and coffee.

\section{Model Specification, the Scope and Source of Data and Methodology}

This section specifies the model, explains the scope and data sources, and presents the research methodology, which determines the way by which the research is done through collecting relevant and appropriate data and information following research aims, objectives and research questions (Saunders et al., 2009). The motivation of this paper is the lack of extensive literature on agricultural commodity levels in Sierra Leone. And also, the inability of the existing literature to develop a measure, which captures the short and long-run impact of variation of the real exchange rate on aggregate cocoa and coffee exports in Sierra Leone. Thus, there is a need to conduct more research in order to fill these gaps to provide relevant information for a policy review. Hence, the topic "Impact of real exchange rate fluctuation on aggregate cocoa and coffee export in Sierra Leone".

Model Specifications: To investigate the impact of real exchange rate fluctuations on aggregate cocoa and coffee exports in Sierra Leone, appropriate aggregate cocoa and coffee export model for this study would be a regression model that combines the effect of both real exchange rate movements with some control variables suggested by conventional trade theory as influencing cocoa and coffee exports. An alternative approach would be a vector autoregressive VAR model to estimate the impact of real exchange rate fluctuations on aggregate cocoa and coffee exports. Employing the regression model to estimate both the short-run and longrun impacts, while utilizing the VAR model and orthogonalized impulse response functions to estimate the short-run impact. Presuming the variables are I(1) and there is no cointegration ${ }^{5}$. The regression model for this analysis is as follows:

$\Delta \operatorname{LogAGX} X_{t}=c+\alpha_{1} \Delta \operatorname{LogRER}_{\mathrm{t}}+\alpha_{2} \Delta \log 2_{\mathrm{t}}+\alpha_{3} \Delta \mathrm{OPEN}_{\mathrm{t}}+\mathrm{U}_{\mathrm{t}}$

Where AGX = Aggregate cocoa and coffee export (tones)

$\mathrm{c}=$ constant parameter

$\mathrm{RER}=$ Real exchange rate

$\mathrm{t}=$ current time subscript

$\Delta=$ first difference

M2 = Broad money supply

OPEN = Trade openness, is a proxy for trade policy.

$\mathrm{U}=$ error term

The analysis includes the variables $\left(\Delta \operatorname{LogM} 2_{t}, \Delta O P E N_{t}\right)$ to control for the effect of certain factors and to introduce dynamics in the relation. The analysis estimates a distributed lag model to determine the shortterm and long-term effects of RER fluctuations on total cocoa and coffee exports. Hence, the impact coefficient $\alpha_{1}$ is the total reaction of cocoa and coffee, including the direct and indirect effects of real exchange rate

${ }^{5}$ This is the characteristics of the series in this analysis. It is in accordance with time-series unit root and cointegration techniques. 
fluctuations (operating through control variables). VAR is specified with $\mathrm{n}$ lags. This model is an alternative model for estimating the short-term impact of RER on total cocoa and coffee exports, so:

$y_{t}=c+A_{1} y_{t-1}+A_{2} y_{t-2}+\ldots . .+A_{n} y_{t-n}+U_{t}$

Where $\mathrm{y}_{\mathrm{t}}=\left(\Delta \log A G X_{\mathrm{t}}, \Delta \operatorname{LogRER} \mathrm{t}_{\mathrm{t}}, \Delta \operatorname{LogM} 2_{\mathrm{t}}, \Delta O \mathrm{OPEN}_{\mathrm{t}}\right), \mathrm{U}_{\mathrm{t}}$ is a vector error of reduced-form shocks. An extended version of the equation includes additional variables. Based on orthogonalized impulse response function(with $\Delta \operatorname{LogAGX} X_{t}$ as the first as well as the impulse variable), the short-run impact is obtained by observing how would $\triangle \log A G X_{t}$ respond to a standard deviation shock to $\Delta \operatorname{LogRER}_{\mathrm{t}}$. Note that, in this paper, an increase in real exchange rates is referred to as a depreciation of the domestic currency, and a decrease is referred as an appreciation of the domestic currency. The essence of introducing a logarithm on some of the variables is to express the parameters in terms of their elasticities and to scale down the variables and therefore reduce the incident of heteroscedasticity.

Scope and Source of Data: The early 1980s were characterized by large fluctuations in aggregate cocoa and coffee exports, which have been blamed mostly on the low producer price of cash crop product; the intensification of the civil war in 1991 caused instability in most productive areas of Sierra Leone. As such the exchange rate could not maintain the stability it gained before 1991 and total tons of cocoa and coffee exports were adversely affected, this study, therefore, collect time series annual data for the period 1980 to 2016 . See Table 2 below for the variables, unit of measurement, and their respective source. Note that, some of the variables have been transformed into natural logarithms so that the regression result can be interpreted as elasticities. That is the response of the dependent variable that is explained by a $1 \%$ increase in the independent variable.

Table2: Variable, Unit of Measurement and Sources

\begin{tabular}{|c|c|c|c|}
\hline No. & Variables & Unit of measurement & Source \\
\hline 1 & Nominal exchange rate (NER) & $\begin{array}{l}\text { The relative price of the } \\
\text { local currency unit per } \\
\text { relative price of the US } \\
\text { dollar (RPLCU/RPUSD). }\end{array}$ & World Bank \\
\hline 2 & Real exchange rate (RER) & Current US dollars & $\begin{array}{l}\text { RER }=\left(\mathrm{NER}^{*} \mathrm{P}_{\mathrm{f}} / \mathrm{P}_{\mathrm{d}}\right) . \\
\mathrm{P}_{\mathrm{f}}=\text { foreign price level (proxy as } \\
\text { USCPI) } \\
\mathrm{P}_{\mathrm{d}}=\text { domestic price level (proxy as } \\
\text { domestic CPI)- (author's calculation) }\end{array}$ \\
\hline 3 & $\begin{array}{l}\text { The United States Consumer } \\
\text { Price Index (USCPI) }\end{array}$ & Current US dollars & World Bank \\
\hline 4 & $\begin{array}{l}\text { Consumer price index (CPI) for } \\
\text { the } \\
\text { economies/countries }\end{array}$ & Current dollar & World Bank \\
\hline 5 & Quantity of cocoa exports (COX) & Tones & $\begin{array}{l}\text { Food and Agricultural Organization } \\
\text { data }\end{array}$ \\
\hline 6 & Quantity of coffee exports (CFX) & Tones & $\begin{array}{l}\text { Food and Agricultural Organization } \\
\text { data }\end{array}$ \\
\hline 7 & $\begin{array}{l}\text { Aggregate cocoa and coffee } \\
\text { exports (AGX) }\end{array}$ & Tones & $\begin{array}{l}\mathrm{AGX}=\mathrm{COX}+\mathrm{CFX} \quad \text { (author's } \\
\text { calculation) }\end{array}$ \\
\hline 8 & Value of cocoa exports & $\begin{array}{l}\text { Current US } \\
\text { (thousand) }\end{array}$ & $\begin{array}{l}\text { Food and Agricultural Organization } \\
\text { data }\end{array}$ \\
\hline 9 & Value of coffee exports & $\begin{array}{l}\text { Current US dollars } \\
\text { (thousand) }\end{array}$ & $\begin{array}{l}\text { Food and Agricultural Organization } \\
\text { data }\end{array}$ \\
\hline 10 & $\begin{array}{l}\text { Exports of goods and services } \\
\text { (X) }\end{array}$ & Current US dollars & World bank \\
\hline 11 & Imports of goods and services & Current US dollars & World bank \\
\hline
\end{tabular}
(M) 


\begin{tabular}{|c|c|c|c|c|}
\hline Gross Domestic Product(GDP) & $\begin{array}{l}\text { Current } \\
\text { (billions) }\end{array}$ & World bank & & \\
\hline Openness (OPEN) & Current US dollars & $\begin{array}{l}\text { OPEN = } \\
\text { calculation) }\end{array}$ & $\mathrm{X}+\mathrm{M} / \mathrm{GDP}$ & (author's \\
\hline Broad Money supply (M2) & Percent of GDP & World bank & & \\
\hline
\end{tabular}

Methodology: Since the primary objective is to check the short and long-run impacts of RER fluctuations on aggregate cocoa and coffee exports. For this, I used the cointegration technique, which states that the variables, LogAGX, LogRER, LogM2, and OPEN are said to be cointegrated if they can be combined linearly and hence exhibit a long-run relationship. On the other hand, if the series are not cointegrated, then the series does not exhibit a long-run relationship. Two types of tests are normally carried out in this analysis; the Johansen cointegration technique, and the Engel-Granger cointegration test. However, this study employs the Johansen cointegration test because of its advantages over the Engle-Granger approach (discussed below). The regression and the VAR models have been employed in this analysis. I use the auto distributed lag regression model to estimate the short and long-run impacts of RER fluctuations on aggregate cocoa and coffee exports. In the VAR model, orthogonalized impulse response functions are employed to estimate the short-run impact of RER movement on aggregate cocoa and coffee exports. The Granger causality test is used to establish a causal relationship between the variables. I discussed these approaches in brief below.

The Unit Root Test: Ullah, et al. (2012), said that almost all the economic variables are non-stationary at their level form which makes the coefficients inconsistent and empirical results spurious. The literature has shown that most macroeconomic variables are not mean reverting as a result of their time sensitiveness, reported by (Uduh 2017). Hence, they are not stationary at their level form. A stationary process is a stochastic process whose unconditional joint probability distribution does not change when shifted in time. Consequently, parameters such as mean $\mu$ and variance $\sigma^{2}$ also do not change over time. Three tests are applicable in the test of stationarity. The Augmented Dickey-Fuller (ADF) test, Philip-Perron (PP) test, and the ADF-Generalizes Least Square test. However, since the variables in this study do not have structural breaks ${ }^{6}$, the research therefore employs the Augmented Dickey-Fuller (ADF) test to check whether the variables are stationary at a level or not (see Kemal and Qadir 2005). The null hypothesis is that a unit root is present in a time series sample. And the alternative hypothesis is different depending on the version of the test, but is usually stationary or trend-stationary. The general model of the ADF is:

$\mathrm{y}_{\mathrm{t}}=\alpha+\mathrm{y}_{\mathrm{t}-1}+\mathrm{Ut}_{\mathrm{t}}$

Where $U_{t}$ is an independent and identically distributed zero-mean error term, presumably $\alpha=0$, which is a random walk without drift, we allow for a drift term by letting $\alpha$ be unrestricted. The Dickey-Fuller test involves fitting the model

$\mathrm{y}_{\mathrm{t}}=\alpha+\rho \mathrm{y}_{\mathrm{t}-1}+\delta_{\mathrm{t}}+\mathrm{U}_{\mathrm{t}}$

by ordinary least squares (OLS), perhaps setting $\alpha=0$ or $\delta=0$. However, such a regression is likely to be plagued by serial correlation. To control for that, the augmented Dickey-Fuller test instead fits a model of the form;

$\Delta \mathrm{y}_{\mathrm{t}}=\alpha+\beta \mathrm{y}_{\mathrm{t}-1}+\delta_{\mathrm{t}}+\zeta_{1} \Delta \mathrm{y}_{\mathrm{t}-1}+\zeta_{2} \Delta \mathrm{y}_{\mathrm{t}-2}+\ldots \ldots \ldots+\zeta_{\mathrm{k}} \Delta \mathrm{y}_{\mathrm{t}-\mathrm{k}}+\varepsilon_{\mathrm{t}}$

Where $\mathrm{k}$ is the number of lags specified and $\Delta$ is the difference. The no-constant option removes the constant term $\alpha$ from this regression, and the trend option includes the time trend $\delta_{\mathrm{t}}$, which is left out by default. Testing $\beta=0$ is equivalent to testing $\rho=1$, or, equivalently, that $y_{t}$ follows a unit root process. In the first case, the null hypothesis is that $y_{t}$ follows a random walk without drift, and (5) is fitted without the constant term $\alpha$ and the time trend $\delta_{\mathrm{t}}$. The second case has the same null hypothesis as the first, except that we include $\alpha$ in the regression. In both cases, the population value of $\alpha$ is zero under the null hypothesis. In the third case, we hypothesize that $y_{t}$ follows a unit root with drift so that the population value of $\alpha$ is non zero; we do not

${ }^{6}$ See cumulative sum test result on page 19. 
include the time trend in the regression. Finally, in the fourth case, the null hypothesis is that $\mathrm{y}_{\mathrm{t}}$ follows a unit root with or without drift so that $\alpha$ is unrestricted, and we include a time trend in the regression.

The one-tailed null and alternative hypotheses are;

$\mathrm{H}_{0}: \beta=0$ or $\rho=1$ (where $\left.\beta=\rho-1\right)$

$H_{a}: \beta \neq 0$ or $\rho \neq 1$

Deciding which case to use involves a combination of theory and visual inspection of the data. If economic theory favors a particular null hypothesis, then we can decide on the appropriate case based on that. If a graph of the data shows an upward trend over time, then case four may be preferred. If the data do not show a trend, but do have a nonzero mean, then case two will be an effective choice. The intuition behind the test is that if the series is characterized by a unit root process, then the lagged level of the series $\left(\mathrm{y}_{\mathrm{t}-1}\right)$ will not provide information in predicting the change in $\left(\mathrm{y}_{\mathrm{t}}\right)$ besides the one obtained in the lagged changes $\left(\Delta \mathrm{y}_{\mathrm{t}-\mathrm{k}}\right)$. In this case, the $\beta=0$ and the null hypothesis is not rejected. On the other hand, when the process has no unit root, it is stationary and hence exhibits reversion to the mean - so the lagged level will provide relevant information in predicting the change of the series and the null of a unit root will be rejected.

Cointegration: Cointegration is a long-run or equilibrium relationship between different random variables (Ullah, et al. 2012). When the variables are I(1) we perform a cointegration to establish a long-run relationship. The popular approaches to cointegration are the Engle-Granger test and the Johansen approach (Kemal and Qadir 2005). The Engle-Granger test is to run a static regression after first having verified that an I (1) process exists, and finally estimate the error correction model. However, this test takes one variable as the dependent variable and the remaining as independent variables, but reversing the order could indicate no cointegration even if the variables are cointegrated (see Kemal and Qadir 2005, for more details on the shortfalls). Thus, in order to overcome the shortfalls of the Engle-Granger test, this study therefore employs the Johansen approach. Johansen's method is the maximum likelihood estimator of the so-called reduced rank model. The general form of the model is;

$\Delta \mathrm{y}_{\mathrm{t}}=\Pi \mathrm{y}_{\mathrm{t}-1}+\Gamma \Delta \mathrm{y}_{\mathrm{t}-1}+\mathrm{e}_{\mathrm{t}}$

Where $\Pi$ is the long-run cointegrating matrix and it contains equilibrium (error) correction terms and $\Gamma$ shows the coefficient of VAR. The existence of a cointegrating relationship depends on the rank of the matrix П.

Impulse Response Function: If the variables in $y_{t}$ are I(1) but not cointegrated, $\Pi$ is a matrix of zeros and thus has rank 0 . This implies that $\Pi$ is a null matrix meaning there is no linear combination. If the variables are $\mathrm{I}(0)$, $\Pi$ has full rank, implying that both rows are linearly independent and the variables are stationary and cannot cointegrate (Kemal and Qadir 2005). When the series is I(1) and have zero cointegrating relationships, we can use a VAR to find out a short-run relationship in the series. VAR models are usually not precise enough to be all that informative from a practical standpoint. This issue is overcome by using an impulse-response function which describes the evolution of the variable of interest along a specified time horizon after a shock in a given moment. It is a useful tool for characterizing the dynamic responses implied by estimated VARs (Kemal and Qadir 2005). Let us first consider the case of a univariate first-order autoregressive AR(1) process:

$\mathrm{x}_{\mathrm{t}}=\varphi_{0}+\varphi_{\mathrm{t}} \mathrm{x}_{\mathrm{t}-1}+\mathrm{e}_{\mathrm{t}}$

Where $\varphi_{0}$ is the vector of intercepts, $\mathrm{x}_{\mathrm{t}}$ is a scalar, $\varphi<1$ (what makes the process stationary) and $\mathrm{e}_{\mathrm{t}}$ is a (scalar) random disturbance with mean 0. This equation is given as the Vector Moving Average (VMA) equation 7 .

$\mathrm{x}_{\mathrm{t}}=\mu+\sum_{\mathrm{i}=1}^{\infty} \varphi_{1}+\mathrm{e}_{\mathrm{t}-1}$

${ }^{7}$ See Walter (1995) for details. 
Kemal and Qadir, (2005) "pointed out that VMA is a basic equation that can track the time path of the various impacts of variables in the VAR system." Thus, in this analysis, the focus is mainly on the impact of standard deviation shocks of real exchange rates, on aggregate cocoa and coffee exports.

Granger Causality Test: After fitting a VAR, we may want to know the direction of the relation between the variables. The Granger Causality test is useful in evaluating the direction of the relation. A variable x Grangercauses a variable $y$ if, given the past values of $y$, the past values of $x$ are useful for predicting $y$. A common method for testing Granger causality is regress y on its own lagged values and lagged values of $\mathrm{x}$ and tests the null hypothesis that the estimated coefficients on the lagged values of $\mathrm{x}$ are jointly zero. Failure to reject the null hypothesis is equivalent to failure to reject the hypothesis that $\mathrm{x}$ will not cause $\mathrm{y}$.

\section{Results Presentation and Interpretation}

Table 3: Correlation Matrix of the Variables (1980-2016)

\begin{tabular}{lllll}
\hline & AGX & RER & M2 & OPEN \\
\hline AGX & I.0000 & & & \\
& & & & \\
RER & $-0.4571^{* *}$ & 1.0000 & & \\
& $(0.00045)$ & & 1.0000 & \\
M2 & $0.5996^{* *}$ & $-0.3737^{*}$ & & \\
& $(0.0001)$ & $(0.0227)$ & 0.0054 & 1.0000 \\
OPEN & 0.1145 & $0.4845^{* *}$ & $(0.9748)$ & \\
& $(0.4998)$ & $(0.0024)$ & \\
\hline
\end{tabular}

Note that the figure in the bracket indicates probability. ${ }^{*}$ and ${ }^{* *}$ indicate statistically significant at the $5 \%$ and $1 \%$ levels, respectively. Table 3 presents the correlation between AGX and other variables, including the RER, M2, and OPEN. The column "AGX" shows that the correlation between AGX and other variables ranges from 0.4571 to 0.5996 and two of them are statistically significant at the $1 \%$ level (with RER and M2). The correlation between AGX and RER is negative, but appears to be weak. And the non-significant between AGX and OPEN suggests that OPEN does not affect AGX.

Table 4: Summary Statistics of the Variables (1980-2016)

\begin{tabular}{lllll}
\hline & AGX & RER & M2 & OPEN \\
\hline Mean & 11487.14 & 3469.64 & 18.12988 & 0.510987 \\
Median & 12213 & 3595.16 & 17.10477 & 0.45906 \\
Standard Deviation & 4809.35 & 685.47 & 5.43748 & 0.178352 \\
Variance & $2.31 \mathrm{e}+07$ & 469865.9 & 29.56619 & 0.031809 \\
Skewness & -0.0288 & -0.37594 & 0.514683 & 0.71095 \\
Kurtosis & 1.872263 & 2.6272 & 2.331598 & 2.732939 \\
Observations & 37 & 37 & 37 & 37 \\
\hline
\end{tabular}

Source: Author's computation using STATA 15

Table 4 provides the summary descriptive statistics for the variables with a sample of 37 observations for each. The mean of AGX is 11487.14, the median value is 12213, the deviation of the sample mean is 4809.35, and whilst the variance is $2.31 \mathrm{e}+07$, which indicates that the observations have certain variations. The skewness is -0.0288 , which means the skewness is negative. While the kurtosis is 1.872263 , meaning lower values below the sample mean. In the case of the RER variable, the mean is 3469.64 , the median value is 3595.16 , and the deviation of the sample mean is 685.47 , whilst the variance is 469865.9 , which indicates that the observations have high variations. The skewness is -0.37594 , which means the skewness is negative. The kurtosis is 2.6272, meaning lower values below the sample mean. Also, the variable M2 shows that the mean is 18.12988, the median value is 17.10477 , and the deviation of the sample mean is 5.43748 , whilst the variance is 29.56619, which indicates that the observations have certain variations. The skewness is 0.514683 , which means that the observed values tend to a normal distribution around the mean. And the kurtosis is 2.331598, meaning lower values below the sample mean. The OPEN variable shows that the mean is 0.510987 , the median value is 0.45906 , and the deviation of the sample mean is 0.178352 , whilst the variance is 0.031809 , which indicates that the observations have certain variations. The skewness is 0.71095 , 
which means that the observed values tend to a normal distribution around the mean. And the kurtosis is 2.732939 , indicating lower values below the sample mean.

Figure 5: Time Series Behavior of the Variables(1980 - 2016)

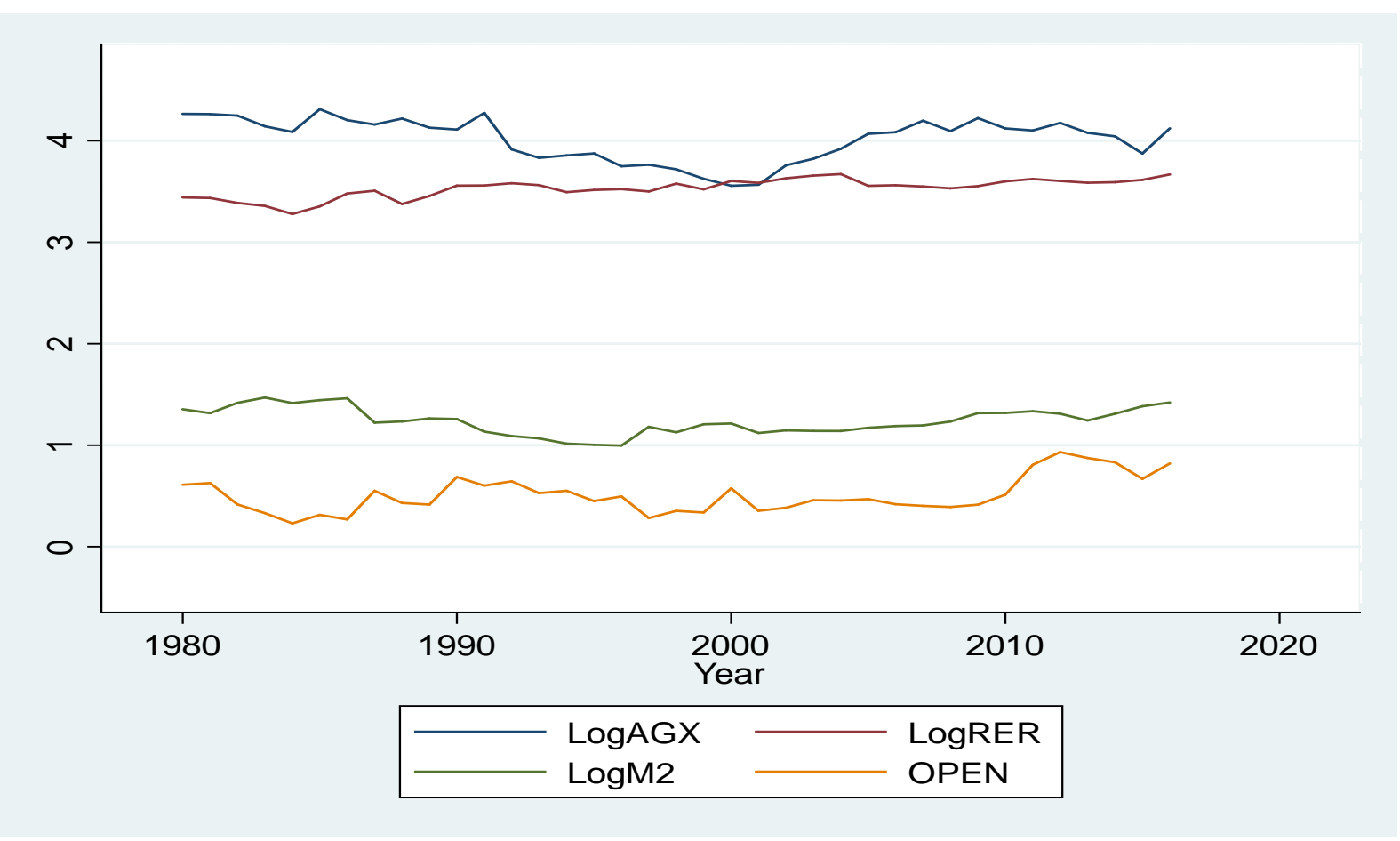

Figure 5 above shows that all the variables are trending, which means that the data generation process does not revolve around zero. Therefore, it shows that the data exhibit the potential of the I (1) process. The time trends in the data appear to be more or less linear. Hence, the study conducts a unit root test on the series as shown in the tables below.

Table 5: Augmented Dickey-Fuller Test Result for Unit Root (Regress Lag 1 for all the Variables)

\begin{tabular}{llllll}
\hline Same Period & Variable & Levels & \multicolumn{3}{c}{ First Difference } \\
\hline & & With intercept & $\begin{array}{l}\text { Without intercept } \\
\text { \& trend }\end{array}$ & With intercept & $\begin{array}{l}\text { Without } \\
\text { intercept } \\
\text { trend }\end{array}$ \\
$1980-2016$ & & & & \\
& & & & & \\
& LogAGX & $-1.664(-2.972)$ & $-1.454(-3.560)$ & $-4.371(-2.975)^{* *}$ & $4.470(-3.564)^{* *}$ \\
& LogRER & $-1.662(-2.972)$ & $-3.261(-3.560)$ & $-5.275(-2.975)^{* *}$ & $-5.191(-3.564)^{* *}$ \\
& LogM2 & $-1.320(-2.972)$ & $-1.087(-3.560)$ & $-4.417(-2.975)^{* *}$ & $-4.870(-3.564)^{* *}$ \\
& OPEN & $-1.632(-2.972)$ & $-2.531(-3.560)$ & $-3.983(-2.975)^{* *}$ & $-3.958(-3.564)^{* *}$ \\
\hline
\end{tabular}

Note: ${ }^{* *}$ indicates significance at the $5 \%$ level. The numbers in columns 3 to 6 in parentheses show the critical value.

In general, the results of the unit root test at the first difference show that the variables are stationary since the probability values exceed the critical values at $5 \%$ for the respective variables, hence, we cannot reject the null hypothesis of a unit root at the first difference, meaning that the variables are stationary at the first difference I(1). Therefore, it is necessary to analyze the long-term relationship through the Johansen cointegration test.

Selecting the Number of Lags: To test for cointegration, we must specify how many lags to include. Table 6 below shows the result of the output after using Stata 15 commands for each model. 
Table 6: Lag Selection Output of the Model

\begin{tabular}{|c|c|c|c|c|c|c|c|c|}
\hline $\begin{array}{l}\text { La } \\
\text { g }\end{array}$ & $\begin{array}{l}\text { Log- } \\
\text { likelihoo } \\
\text { d } \\
\text { (LL) }\end{array}$ & $\begin{array}{l}\text { Likelihoo } \\
\text { d Ratio } \\
\text { (LR) }\end{array}$ & $\begin{array}{l}\text { Degree } \\
\text { of } \\
\text { Freedo } \\
\text { m (DF) }\end{array}$ & $\begin{array}{l}\text { Probabilit } \\
\text { y }\end{array}$ & $\begin{array}{l}\text { Final } \\
\text { Predictio } \\
\text { n Error } \\
\text { (FPE) }\end{array}$ & $\begin{array}{l}\text { Akaike } \\
\text { Informatio } \\
\text { n Criterion } \\
\text { (AIC) }\end{array}$ & $\begin{array}{l}\text { Hannan- } \\
\text { Quinn } \\
\text { informatio } \\
\text { n Criterion } \\
\text { (HQIC) }\end{array}$ & $\begin{array}{l}\text { Schwarz } \\
\text { Bayesian } \\
\text { Informatio } \\
\text { n Criterion } \\
\text { (SBIC) }\end{array}$ \\
\hline 0 & 88.1957 & & & & & & -5.04173 & -4.92137 \\
\hline 1 & 152.46 & 128.53 & 16 & 0.000 & 9* & $-8.02785^{*}$ & $-7.72268 *$ & $-7.12088^{*}$ \\
\hline 2 & 165.441 & 25.962 & 16 & 0.0 & $4.9 \mathrm{e}-09$ & -7.84489 & -7.29558 & -6.21234 \\
\hline 3 & 176.228 & 21.574 & 16 & 0.157 & $7.6 e-09$ & -7.52896 & -6.73552 & -5.17082 \\
\hline 4 & 190.954 & $29.452^{*}$ & 16 & 0.021 & $1.1 \mathrm{e}-08$ & -7.45173 & -6.41415 & -4.36802 \\
\hline
\end{tabular}

From the output in Table 6 above, the FPE, AIC, HQICandSBIC methods all choose lag one (L1), as indicated by the “*” in the output. Hence, since four criteria, select one lag, this study will use L1.

Johansen Co-Integration Test: Here, there are two statistics; the trace statistics and the maximum statistics. For both test statistics, the Johansen test the null hypothesis of no cointegration against the alternative of cointegration. Table 7 below shows the output of the Johansen cointegration test.

Table 7: Output of Johansen Cointegration Test [lag (L) 1]

Panel A: Unrestricted Cointegration Test - Trace Statistics

\begin{tabular}{|c|c|c|c|}
\hline $\begin{array}{l}\text { Hypothesized No. of } \\
\text { CE (S) }\end{array}$ & Eigenvalue & Trace Statistics & $5 \%$ Critical Value \\
\hline 0 & 0.00000 & 23.2265 & 29.68 \\
\hline 1 & 0.33236 & 8.6822 & 15.41 \\
\hline 2 & 0.13624 & 3.4096 & 3.76 \\
\hline
\end{tabular}

Panel B: Unrestricted Cointegration Test- Maximum-Eigen Statistic

\begin{tabular}{|c|c|c|c|}
\hline $\begin{array}{l}\text { Hypothesized No. of } \\
\text { CE (S) }\end{array}$ & Eigenvalue & Maximum-Eigen Statistic & $5 \%$ Critical Value \\
\hline 0 & 0.00000 & 14.5443 & 20.97 \\
\hline 1 & 0.33236 & 5.2725 & 14.07 \\
\hline 2 & 0.13624 & 3.4096 & 3.76 \\
\hline
\end{tabular}

$\mathrm{CE}(\mathrm{s})$ : Cointegrating equation

Table 7 shows the results of the Johansen cointegration test for the aggregate export model of cocoa and coffee. The results show both the trace and maximum statistics at a $5 \%$ critical level. From the outputs of both statistics, the analysis strongly fails to reject the null hypothesis of no cointegration. Thus, the study accepts the null hypothesis at the maximum rank of zero (0) that there is no cointegration between the variables. This implies that the variables exhibit a short-run relationship. The reduction in imports that follows decreases the output and hence cocoa and coffee exports. However, this variable is not significant in determining aggregate cocoa and coffee exports in Sierra Leone. The existence of no cointegration between the dependent variable and the fundamentals necessitates estimating a VAR model to find out the short-run impact.

Table 8: The Estimated Aggregate Cocoa and Coffee Exports, Auto-Distributed Regression Output Model

\begin{tabular}{llllll}
\hline$\Delta$ LogAGX & & & \\
$\mathbf{t}-1$ & Constant & $\Delta$ LogRER $_{\mathbf{t}}$ & $\Delta$ LogRER $_{\mathbf{t}-1}$ & $\mathbf{R}^{\mathbf{2}}$ & Probability $>\mathbf{F}$ \\
\hline Coefficient & -0.0118592 & 0.4677226 & -0.3686428 & & \\
$\mathrm{~T}$ & -0.56 & 1.04 & -0.82 & 0.0654 & 0.9173 \\
$\mathrm{P}>|\mathrm{t}|$ & 0.577 & 0.308 & 0.421 & & \\
Standard Error & 0.0210244 & 0.4504047 & 0.4517941 & & \\
\hline
\end{tabular}

Note: I only show the estimate of the total output of cocoa and coffee exports and RER.

The aggregate cocoa and coffee exports in table 9 show that while the depreciation of the real exchange rate increases aggregate cocoa and coffee exports in the current year, this variable is not significant in 
determining aggregate cocoa and coffee exports in Sierra Leone. The reason for the insignificant results may be that the production period of cocoa and coffee is relatively long, and before this period ends, suppliers cannot increase production and therefore cannot increase exports. Also, the negative effect of the one-period lag of real exchange rate variable on aggregate cocoa and coffee exports may be as a result of the fact that in the long run, depreciation in the nominal exchange rate leads to a real exchange rate depreciation, which leads to increase in the cost of imported inputs in domestic currency terms. Because the probability $>\mathrm{F}=$ 0.9173, the study concluded that the variables do not jointly affect Sierra Leone's total cocoa and coffee exports.

The output of the Diagnostic Test of the Autoregressive Distributed Lag Model (the rejection is at the 5 \% level): The Shapiro-Wilk W test for normal data shows that Probability $>z=0.09188$; thus the study concludes that the distribution of the residuals is normal. Breusch-Pagan / Cook-Weisberg test for heteroskedasticity indicates that Probability $>\mathrm{chi}^{2}=0.9689$; which suggests that the residuals are homoscedastic. Also, Durbin's alternative test for autocorrelation shows that Probability > chi ${ }^{2}=0.5541$; implying that there is no serial correlation in the residuals. On the same note, the Breusch-Godfrey LM test for autocorrelation shows that Probability $>\mathrm{chi}^{2}=0.5034$; this also supports the conclusion that there is no serial correlation in the residuals.

Vector Autoregressive (VAR) Model: The VAR model can determine the relationship between multiple variables, and it is useful for forecasting, but the forecasts are usually not precise enough. Instead, researchers will usually end up looking at the following: Impulse response functions and Granger causality test, which reveal something about the nature of the variables. This paper employs the impulse response function to determine the relationship between the dependent and the policy variables, and the Granger causality test to investigate whether the variables are jointly significant or not.

Table 9: Output of Vector Autoregression

\begin{tabular}{|c|c|c|c|c|c|c|}
\hline Equation & Parms & RMSE & $\mathbf{R}^{2}$ & & $\mathrm{Chi}^{2}$ & P>chi ${ }^{2}$ \\
\hline D_LogAGX & 5 & 0.127323 & 0.0542 & & 2.00432 & 0.7350 \\
\hline D_LogRER & 5 & 0.053451 & 0.2305 & & 10.48358 & 0.0330 \\
\hline D_LogM2 & 5 & 0.070621 & 0.1438 & & 5.878139 & 0.2084 \\
\hline D_OPEN & 5 & 0.130645 & 0.1560 & & 6.471082 & 0.1666 \\
\hline & Coefficients & Std. Error & $\mathbf{z}$ & $\mathbf{P}>|\mathbf{z}|$ & \multicolumn{2}{|c|}{ [95\%Confidence Interval] } \\
\hline $\begin{array}{l}\text { D_LogAGX } \\
\text { LD. } \\
\text { LogRER }\end{array}$ & -0.2310289 & 0.178406 & -1.29 & 0.195 & -0.5806982 & 0.1186403 \\
\hline $\begin{array}{l}\text { LD. } \\
\text { LogM2 }\end{array}$ & -0.1431299 & 0.4073832 & -0.35 & 0.725 & -0.9415864 & 0.6553265 \\
\hline $\begin{array}{l}\text { LD. } \\
\text { OPEN }\end{array}$ & 0.0095228 & 0.3020876 & 0.03 & 0.975 & -0.5825581 & 0.6016037 \\
\hline LD. & 0.1186994 & 0.1855822 & 0.64 & 0.522 & -0.2450352 & 0.4824339 \\
\hline Constant & -0.0060873 & 0.0200864 & -0.30 & 0.762 & -0.0454558 & 0.0332813 \\
\hline
\end{tabular}

As we can see from the output in Table 10 above, when lagging by one (L1), there is a negative but negligible effect between $\triangle \operatorname{LogRER}$ and $\triangle \operatorname{LogAGX}$. The results also show that there is a positive and insignificant effect between $\triangle \operatorname{LogM} 2$ and $\triangle \operatorname{LogAGX}$ in L1. Furthermore, the result reveals a positive, but insignificant relationship between $\triangle$ LogOPEN and $\triangle$ LogAGX in L1. The diagnostic test of the Lagrange-multiplier concludes that there is no autocorrelation, implying correct specification of the model. The Jarque-Bera test also shows that the distribution of the residuals is normal, and the vector autoregressive model VAR satisfies the Eigenvalue stability condition. Varwale test shows that in all equations, the coefficients on the lag of the endogenous variables are jointly zero. And the Cumulative sum test reveals that the parameters are stable over the analysis period. The graph below shows the impulse response function (IRF) to examine the response of aggregate cocoa and coffee export for a standard deviation shock to $\Delta$ LogRER. 
Figure 6: Impulse Response Function

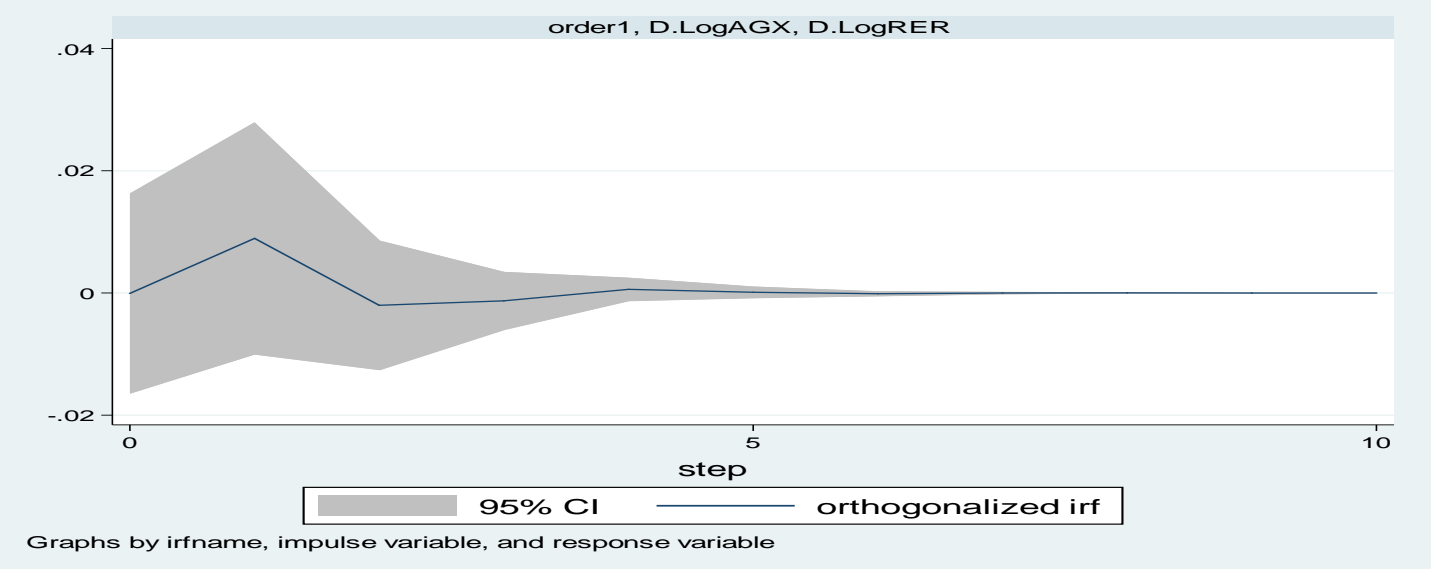

From figure 6 , a shock to $\triangle$ LogRER causes an increase in $\triangle$ LogAGX, followed by a decrease, followed by an increase, until the effect dies out after roughly four periods.

Table 10: Display of the Irf Results (Irf Name = Order 1)

\begin{tabular}{llll}
\hline Step & (1) Orthogonalized irf & (1) Lower & (1) Upper \\
\hline 0 & -0.000071 & -0.016466 & 0.016323 \\
1 & 0.00894 & -0.010074 & 0.027954 \\
2 & -0.002017 & -0.012607 & 0.008573 \\
3 & -0.001284 & -0.006023 & 0.003455 \\
4 & 0.000597 & -0.001317 & 0.002511 \\
5 & 0.000115 & -0.000837 & 0.001066 \\
6 & -0.000118 & -0.000537 & 0.000301 \\
7 & $-2.2 \mathrm{e}-06$ & -0.000202 & 0.000198 \\
8 & 0.000021 & -0.000072 & 0.000114 \\
9 & $-2.9 \mathrm{e}-06$ & -0.000046 & 0.00004 \\
10 & $-3.2 \mathrm{e}-06$ & -0.000023 & 0.000017 \\
\hline
\end{tabular}

Table 10 report $95 \%$ lower and upper bounds with, impulse $=\Delta$ LogAGX, and response $=\Delta$ LogRER. Both the table and the graph show that the two orthogonalized IRFs are essentially the same. In both functions, an increase in the orthogonalized shock to $\triangle$ LogRER causes a short series of increases in $\triangle$ LogAGX followed by a decrease, followed by an increase that dies out after four periods. The output below shows the Granger causality test to ascertain whether the variables are jointly significant in the short run or not.

Table 11: Output of the Granger Causality Test

\begin{tabular}{|c|c|c|c|c|}
\hline Equation & Excluded & $\mathrm{Chi}^{2}$ & $\begin{array}{l}\text { Degree of Freedom } \\
\text { (df) }\end{array}$ & Probability $>\mathrm{Chi}^{2}$ \\
\hline D_LogAGX & D.LogRER & 0.12344 & 1 & 0.725 \\
\hline D_LogAGX & D.LogM2 & 0.00099 & 1 & 0.975 \\
\hline D_LogAGX & D.OPEN & 0.40909 & 1 & 0.522 \\
\hline D_LogAGX & ALL & 0.45493 & 3 & 0.929 \\
\hline
\end{tabular}

Note: Significant level is at $5 \%$, and df is degrees of freedom.

From table 11, the first is a Wald test that the coefficients on the lag of D.LogRER that appear in the equation for D_LogAGX are jointly zero. The study accepts the null hypothesis that the lag of $\triangle$ LogRER does not Granger-cause $\Delta_{-} \operatorname{LogAGX}$. Similarly, we cannot reject the null hypothesis that the lag of D.LogM2 does not Granger-cause D_LogAGX. Again, the null hypothesis that the lag of D.OPEN does not Granger-cause D_LogAGX cannot be rejected. On the whole, we cannot reject the joint probability that the lags of D.LogRER, D.LogM2, and D.OPEN do not Granger-cause D_LogAGX. 


\section{The output of the Diagnostic Test of the VAR Model}

Table 12: Lagrange-Multiplier Test

\begin{tabular}{llll}
\hline Lag & Chi2 & DF & Prob > Chi $\mathbf{~}^{\mathbf{2}}$ \\
\hline 1 & 10.6238 & 16 & 0.83209 \\
\hline
\end{tabular}

From table 12 above, since the probability is greater than the critical value at $5 \%$, the study accepts the null hypothesis and concludes that there is no autocorrelation. Thus, the model is correctly specified.

Table 13: Jarque-Bera Test

\begin{tabular}{|c|c|c|c|}
\hline Equation & $\mathbf{C h i}^{2}$ & DF & Prob > Chi ${ }^{2}$ \\
\hline ALL & 4.192 & 8 & 0.83939 \\
\hline \multicolumn{4}{|c|}{$\begin{array}{l}\text { From table } 13 \text { above, since the probability for all equations is greater than the critical value at } 5 \% \text {, the study } \\
\text { accepts the null hypothesis and concludes that the residuals are normally distributed. }\end{array}$} \\
\hline \multicolumn{4}{|c|}{ Table 14: Eigenvalue Stability Condition } \\
\hline Eigenvalue & & & Modulus \\
\hline$-0.07776085+0.4094602 \mathrm{i}$ & & & 0.416779 \\
\hline - $0.07776085-0.4094602 \mathrm{i}$ & & & 0.416779 \\
\hline$-0.1881609+0.1082357 i$ & & & 0.21707 \\
\hline$-0.1881609-0.1082357 \mathrm{i}$ & & & 0.21707 \\
\hline
\end{tabular}

Because the modulus of each eigenvalue is strictly less than 1, the estimates satisfy the eigenvalue stability condition. Specifying the graph option produced a graph of the eigenvalues with the real components on the $\mathrm{x}$-axis and the complex components on the $\mathrm{y}$-axis. The graph below indicates visually that these eigenvalues are well inside the unit circle.

Figure 7: Below Shows a Plot of the Eigenvalues

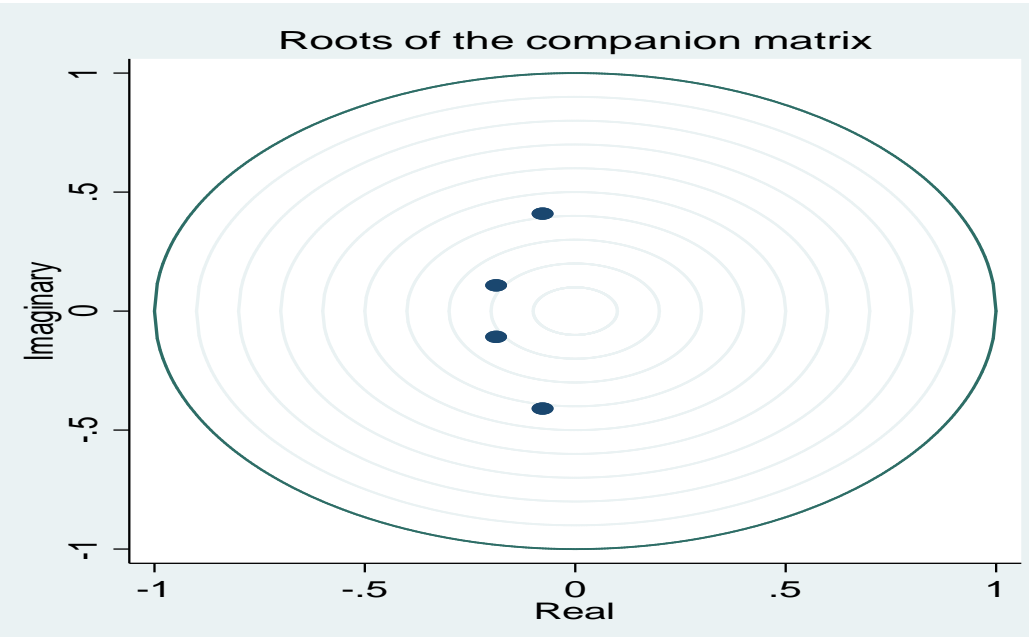

From figure 7, all the eigenvalues lie inside the unit circle. This implies that VAR satisfies stability conditions. After fitting a VAR, one hypothesis of interest is that all the endogenous variables at a given lag are jointly zero. (Ho: endogenous variables are jointly zero. Ha: endogenous variables are not zero). Reject Ho, if Probability is less than 5\%, otherwise, accept.

Table 15: The Estimated Result of Varwale

\begin{tabular}{llll}
\hline Lag & $\mathbf{C h i}^{2}$ & DF & Prob $>\mathbf{C h i}^{\mathbf{2}}$ \\
\hline 1 & 21.27789 & 16 & 0.168 \\
\hline From table 16, On the whole, I strongly cannot reject the null hypothesis that the coefficients on the lag of the \\
endogenous variables are zero in all the equations jointly. Thus, confirming the fact that there is no joint \\
causality running from the endogenous to the exogenous variables.
\end{tabular}




\section{Table 16: Cumulative Sum Test for Parameter Stability}

\begin{tabular}{llllll}
\hline Variable & Statistic & Test Statistic & $\begin{array}{l}\mathbf{1 \%} \\
\text { Critical Value }\end{array}$ & $\begin{array}{l}\mathbf{5 \%} \\
\text { Critical Value }\end{array}$ & $\begin{array}{l}\mathbf{1 0 \%} \\
\text { Critical Value }\end{array}$ \\
\hline D.LogAGX & recursive & 0.2661 & 1.1430 & 0.9479 & 0.850 \\
D.LogRER & recursive & 0.3785 & 1.1430 & 0.9479 & 0.850 \\
D.LogM2 & recursive & 0.3785 & 1.1430 & 0.9479 & 0.850 \\
D.OPEN & recursive & 0.4310 & 1.1430 & 0.9479 & 0.850 \\
\hline
\end{tabular}

From table 16 above the null hypothesis is that all parameters are stable over time (Ho: No structural break), no alternative hypothesis is required. We reject this null hypothesis based on the test statistic being larger than a critical value or based on the plotted cusum being outside the confidence bands. Thus, based on the result, I accept the null hypothesis of a constant mean at the $1 \%$ level for all the variables, because the test statistic values of the first difference of all the variables are lesser than the respective values at the $1 \%$ critical level. We can also observe the cusum plots from figures $8 \mathrm{a}, \mathrm{b}, \mathrm{c}$, and $\mathrm{d}$; we see that the plots of the recursive cusum process are within the $99 \%$ confidence bands in each graph, which implies that the mean of the regression model is stable at the $1 \%, 5 \%$, or $10 \%$ significance levels.

Figures 8a: Below Show Recursive Cusum Plot of the First Difference of the Variables

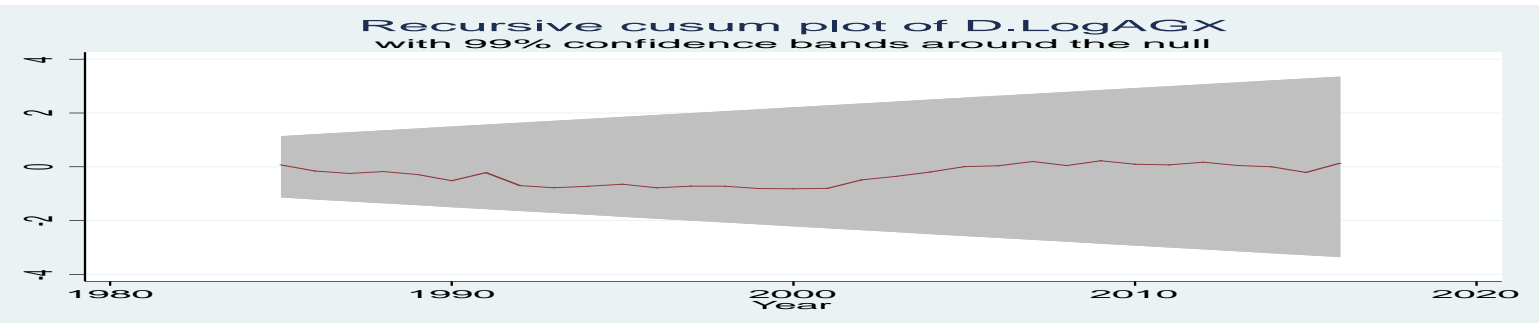

Figure 8b

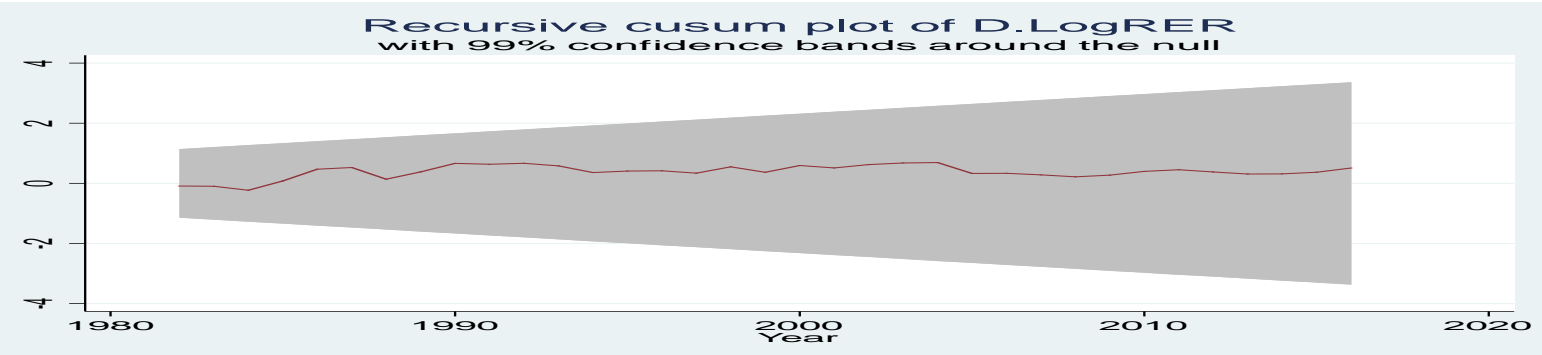

Figure 8c

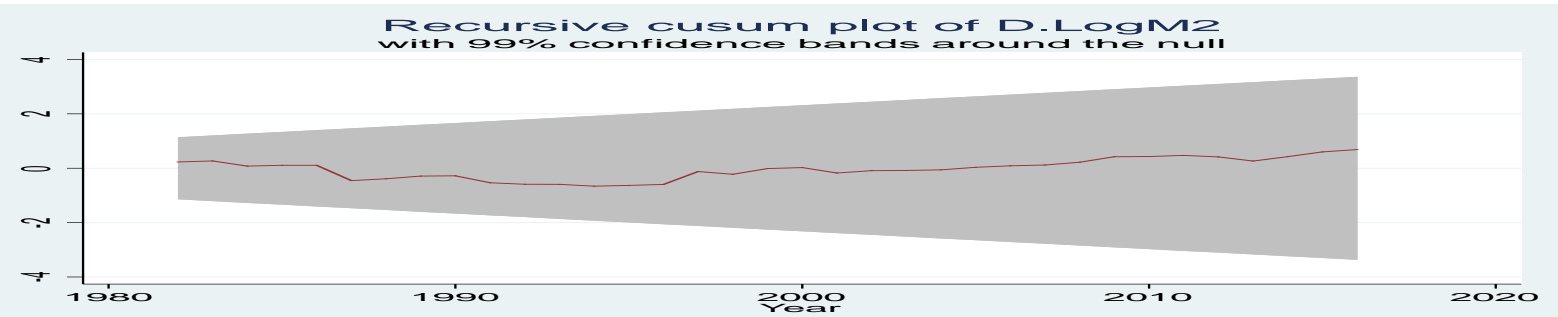

Figure 8d

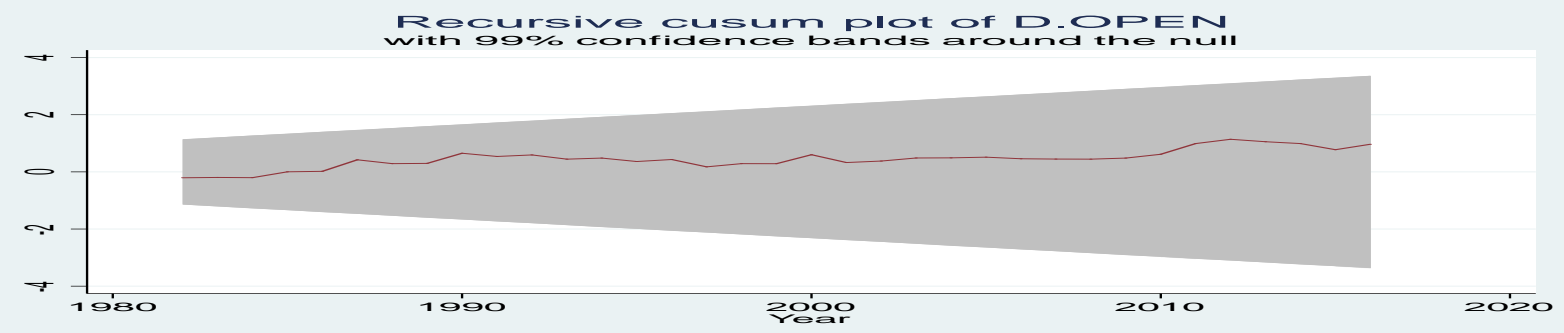




\section{5: Conclusion and Policy Recommendations}

Conclusion: Ultimately, answers have been provided to the two research questions raised which ultimately led to the achievement of the objectives and aim of this study. The regression and the VAR models have been employed in this analysis. I use the auto distributed lag regression model to estimate both the short and the long-run impacts of RER fluctuations on aggregate cocoa and coffee exports. In the VAR model, orthogonalized impulse response functions are employed to estimate the short-run impact of RER movement on aggregate cocoa and coffee exports. The Granger causality test is used to establish a causal relationship between the variables. The regression result shows that while the depreciation of the real exchange rate increases aggregates cocoa and coffee export in the current year, this variable is not significant in determining aggregate cocoa and coffee exports in Sierra Leone. The case for insignificant is because aggregate cocoa and coffee exports have long gestation periods and until this period is over, suppliers cannot raise their output and hence exports. The negative effect of the one-period lag of the RER variable on aggregate cocoa and coffee export can be attributed to the fact that in the long run, depreciation in the nominal exchange rate leads to real exchange rate depreciation which will lead to increase in the cost of imported inputs in domestic currency terms. The reduction in imports that follows decreases the output and hence cocoa and coffee exports. However, this variable is not significant in determining aggregate cocoa and coffee exports in Sierra Leone. Figure 6 and table 10 show that the two orthogonalized impulse response functions are essentially the same.

In both functions, an increase in the orthogonalized shock to $\triangle$ LogRER causes a short series of increases in $\Delta$ LogAGX followed by a decrease, followed by an increase that dies out after four periods. The study accepts the null hypothesis that the lag of $\Delta$ LogRER does not Granger-cause $\Delta_{-} \log A G X$. In general, we cannot reject the joint probability that the lags of $\triangle$ LogRER, $\Delta$ LogM2, and $\triangle$ OPEN do not Granger-cause $\Delta_{-} \operatorname{LogAGX}$. The short-run analysis suggests that the estimate based on the regression equation tends to be similar to the orthogonalized impulse response function derived from the VAR model. Thus, confirming the fact that there is no joint causality running from the endogenous to the exogenous variables. It is interesting to note that, the insignificant relation between the real exchange rate and aggregate cocoa and coffee exports obtained in this study does not agree with the findings of Tarawalie et al. (2013); and Bahmani-Oskooee and Gelan (2018) even though they considered total exports of all commodities in Sierra Leone. However, the study does agree with the study of Akinniran and Olatunji (2018) even though they considered all agricultural products except natural rubber in the SAP and pre SAP periods in Nigeria. For future research, students or prospective researchers should consider including more variables and increase the scope of observations. This is to ascertain any different results. And also, researchers can include the nominal exchange rate to ascertain whether there would be differences in the outcome of the analysis when using either real exchange rate or nominal exchange rate.

Policy Recommendations: In the short and long term, the government should not use the depreciation of the real exchange rate as a policy tool to promote the total export of cocoa and coffee products. However, in order to stimulate the total export of cocoa and coffee, the government should allocate more resources to increase productivity, thereby increasing the export of high-quality cocoa and coffee products. A joint government and private sector participation and mobilization of foreign aid geared towards improving cocoa and coffee production and exports should be encouraged, and also the government should maintain a peaceful political atmosphere to improve the confidence of cocoa and coffee farmers.

\section{References}

Akinniran, T. N. (2018). Effects of Exchange Rate on Agricultural Export in Nigeria. International Journal of Engineering Science Invention (IJESI), 7, 2319 - 6734.

Bahmani-Oskooee, M. \& Gelan, A. (2018). Exchange-rate volatility and international trade performance: Evidence from 12 African countries. Economic Analysis and Policy, 58, 14-21.

Betten, D. S. \& Belongia, M.T. (1984). The recent decline in Agricultural Exports: Is the exchange rate the culprit?Federal Reserve Bank of St. Louis.

Bouoiyour, J. \& Selmi, R. (2013). Exchange rate uncertainty and export performance: what meta-analysis reveals? Munich Personal RePEc Archive - MPRA, 49249. 
Caglayan, M. \& Di, J. (2010). Does Real Exchange Rate Volatility Affect Sectoral Trade Flows? Southern Economic Journal, 77(2), 313-335.

Cao-Alvira, J. (2014). Real Exchange Rate Volatility on the Short and Long-Run Trade Dynamics in Colombia. The International Trade Journal, 28(1), 45-64.

Edwards, S. (1989). Real Exchange Rate in Developing Countries: Concepts and Measurements. Working Paper, National Bureau of Economic Research (NBER), 2950.

Walter, E. (1995). Applied Econometric Time Series. John Willey \& Sons.

Fosu, K.Y. (1992). The Real Exchange Rate and Ghana's Agricultural Export. Internet source.

Hossain, T. (2018). Effects of Exchange Rates on Agricultural Exports: A Special Reference to Bangladesh. Available online at http://www.research gate.net/ publications, 1-13.

Huchet-Bourdon, M. \& Korinek, J. (2011). To What Extent Do Exchange Rates and their Volatility Affect Trade? OECD Trade Policy Papers, OECD Publishing, 119.

Jiang, W. (2014). The Effect of RMB Exchange Rate Volatility on Import and Export Trade in China. International Journal of Academic Research in Business and Social Sciences, 4(1), 2222-6990.

Kemal, Ali, M. \& Qadir, U. (2005). Real Exchange Rate, Exports, and Imports Movements: A Trivariate Analysis. The Pakistan Development Review, 44(2), 177-195.

Khalighi, L. \& Fadaei, M. S. (2017). A study on the effects of the exchange rate and foreign policies on Iranians dates export. Journal of the Saudi Society of Agricultural Sciences, 16, 112-118.

Kristinek, J. J. \& Anderson, D. P. (2002). Exchange rate and agriculture: A literature review. Agricultural and Food Policy Center (AFPC) Working Paper, 02-2.

Orden, D. (2002). Exchange Rate Effects on Agricultural Trade. Journal of Agricultural and Applied Economics, 34, 303-312.

Population by country; (www.worldometers.info)

Review of ongoing agricultural development effort in Sierra Leone. Available online at www.resakss.org, 1.

Review of past agricultural policies in Sierra Leone. Available online at www.fao.org, 17-19.

Sandu, C. \& Ghiba, N. (2011). The Relationship between Exchange Rate and Exports in Romania using a Vector Autoregressive Model. Annales Universitatis Apulensis Series Oeconomica, Internet source, 13(2).

Saunders, M., Lewis, P. \& Thornhill, A. (2009). Research methods for business students. Pearson Education Publications Ltd.

Serenis, D. \& Tsounis, N. (2013). Exchange Rate Volatility and Foreign Trade: The case for Cyprus and Croatia. Procedia Economics and Finance, 5, 677-685.

Serenis, D. \& Tsounis, N. (2014). Does Exchange Rate Variation Effect African Trade Flows? Procedia Economics and Finance, 14, 565-574.

Serenis, D. \& Tsounis, N. (2012). A new approach for measuring the volatility of the exchange rate. Procedia Economics and Finance, 374-382.

Shane, M., Roe, T. \& Somwaru, A. (2008). Exchange Rates, Foreign Income, and U.S. Agricultural Exports. Agricultural and Resource Economics Review, 37(2), 160-175.

Sierra Leone economy.com. (2019). Internet source.

Snape, R. H. (1988). Real exchange rate, real interest rate, and agriculture. Conference paper: Agriculture and government in an independent world. Proceedings of the Twentieth International Conference of Agricultural Economists.

Srinivasan, P. \& Kalaivani, M. (2013). Exchange rate volatility and export growth in India: An ARDL bounds testing approach. Decision Science Letters, 191-202.

Tarawalie, A. B., Sissoho, M., Conte, M. \& Ahortor, C.R. (2012). Exchange Rate, Inflation, and Macroeconomic Performance in the West Africa Monetary Zone. WAMI Occasional papers presented to the technical Committee during the WAMZ Convergence.

Tarawalie, A. B., Sissoho, M., Conte, M. \& Ahortor, C.R. (2013). Export performance and Exchange Rate Volatility. Evidence from the West Africa Monetary Zone. WAMI occasional paper series, 1.

Uduh, D. M. (2017). Impact of Exchange Rate on Cocoa Export in Nigeria. International Journal of Economics, Commerce, and Management, V(5), 2348-0386.

Ullah, S., Zeeshan, S., Haider, S. Z. \& Azim, P. (2012). Impact of Exchange Rate Volatility on Foreign Direct Investment: A Case Study of Pakistan. Pakistan Economic and Social Review, 50(2), 121-138.

Wondemu, K. \& Potts, D. (2016). The Impact of the Real Exchange Rate Changes on Export Performance in Tanzania and Ethiopia. Working Paper Series. African Development Bank, 240. 
Zafar, M. \& Ahmad, K. (2011). Export Growth and Volatility of Exchange Rate: A Panel Data Analysis. Business and Social Sciences Review (BSSR), 1(4), 2047-6485.

\section{Appendix}

Appendix 1: Data Used in the Analysis

\begin{tabular}{|c|c|c|c|c|c|c|c|c|c|}
\hline Year & $\begin{array}{l}\text { Total } \\
\text { cocoa } \\
\text { exports } \\
\text { CoX } \\
\text { (tons) } \\
\end{array}$ & $\begin{array}{l}\text { Total } \\
\text { coffee } \\
\text { exports } \\
\text { CFX } \\
\text { (tons) } \\
\end{array}$ & $\begin{array}{l}\text { Export } \\
\text { value } \\
\text { of } C O X \\
(1000 \\
\text { US\$) }\end{array}$ & $\begin{array}{l}\text { Export } \\
\text { value } \\
\text { of CFX } \\
(1000 \\
\text { US\$) }\end{array}$ & RER & OPEN & M2 & $\begin{array}{l}\text { GDP } \\
\text { (Current US\$ } \\
\text { in billions) }\end{array}$ & $\begin{array}{l}\text { Value of } \\
\text { Agriculture, } \\
\text { including } \\
\text { Forestry and } \\
\text { Fisheries } \\
\text { (US\$ in } \\
\text { billions) }\end{array}$ \\
\hline 1980 & 8497 & 9909 & 22739 & 27891 & 2764.762 & 0.610818 & 22.569 & 1100685845 & 334349400 \\
\hline 1981 & 9026 & 9288 & 13662 & 16982 & 2730.016 & 0.627534 & 20.711 & 1114830472 & 326977828 \\
\hline 1982 & 9043 & 8658 & 14602 & 14559 & 2441.050 & 0.416890 & 26.154 & 1295361886 & 435151173 \\
\hline 1983 & 8315 & 5562 & 13579 & 9983 & 2277.276 & 0.331059 & 29.442 & 995104305 & 363862029 \\
\hline 1984 & 10289 & 1924 & 23180 & 4410 & 1896.285 & 0.230299 & 25.966 & 1087471862 & 419530270 \\
\hline 1985 & 10224 & 10237 & 21318 & 27813 & 2257.592 & 0.314318 & 27.781 & 856890499 & 366685591 \\
\hline 1986 & 8586 & 7383 & 23405 & 19578 & 3023.599 & 0.269270 & 28.963 & 490181457 & 170240293 \\
\hline 1987 & 8779 & 5681 & 20893 & 17312 & 3216.304 & 0.551531 & 16.675 & 701307602 & 297799354 \\
\hline 1988 & 8531 & 8026 & 12221 & 14243 & 2380.843 & 0.431162 & 17.136 & 1055083945 & 456993594 \\
\hline 1989 & 8202 & 5246 & 9168 & 7997 & 2855.211 & 0.415884 & 18.350 & 932974412 & 396594540 \\
\hline 1990 & 4700 & 8200 & 6423 & 8072 & 3612.140 & 0.686907 & 18.110 & 649644827 & 286029665 \\
\hline 1991 & 12600 & 6200 & 13000 & 5900 & 3622.484 & 0.602440 & 13.630 & 779981459 & 286604579 \\
\hline 1992 & 3900 & 4323 & 4000 & 2782 & 3813.486 & 0.644929 & 12.319 & 679997998 & 244032839 \\
\hline 1993 & 3525 & 3255 & 3665 & 2551 & 3650.041 & 0.528598 & 11.690 & 768812335 & 309850220 \\
\hline 1994 & 3400 & 3778 & 4300 & 4339 & 3117.846 & 0.551601 & 10.373 & 911915971 & 341012442 \\
\hline 1995 & 2800 & 4700 & 3600 & 9300 & 3274.857 & 0.450293 & 10.095 & 870758739 & 347907839 \\
\hline 1996 & 4000 & 1600 & 5000 & 2600 & 3337.419 & 0.495955 & 9.926 & 941742153 & 425763006 \\
\hline 1997 & 2900 & 2900 & 4000 & 6500 & 3167.315 & 0.282780 & 15.175 & 850218034 & 487987774 \\
\hline 1998 & 2730 & 2500 & 3800 & 4400 & 3780.770 & 0.353327 & 13.402 & 672375927 & 399405219 \\
\hline 1999 & 2870 & 1350 & 3500 & 1850 & 3324.740 & 0.337492 & 16.077 & 669384769 & 400737169 \\
\hline 2000 & 1500 & 2100 & 1700 & 2000 & 4019.165 & 0.575300 & 16.357 & 635874002 & 349820754 \\
\hline 2001 & 2453 & 1237 & 2586 & 1701 & 3843.094 & 0.354244 & 13.184 & 1090467712 & 492197367 \\
\hline 2002 & 2566 & 3156 & 3605 & 1601 & 4266.109 & 0.383858 & 14.011 & 1253340520 & 579221874 \\
\hline 2003 & 4608 & 2038 & 8065 & 1337 & 4535.630 & 0.459060 & 13.823 & 1385810072 & 642414080 \\
\hline 2004 & 7387 & 950 & 10428 & 592 & 4692.186 & 0.455881 & 13.811 & 1448536631 & 702338286 \\
\hline 2005 & 11088 & 634 & 14078 & 547 & 3595.156 & 0.468728 & 14.860 & 1650494367 & 815203123 \\
\hline 2006 & 10419 & 1727 & 13563 & 1853 & 3647.130 & 0.419128 & 15.442 & 1885112202 & 948099973 \\
\hline 2007 & 13580 & 2194 & 20275 & 3404 & 3538.268 & 0.402954 & 15.671 & 2158496873 & 1126218347 \\
\hline 2008 & 11411 & 1042 & 23087 & 2077 & 3391.341 & 0.392135 & 17.105 & 2505458705 & 1344266495 \\
\hline 2009 & 11422 & 5275 & 23000 & 8755 & 3570.638 & 0.414365 & 20.690 & 2453899847 & 1356046715 \\
\hline 2010 & 10780 & 2455 & 27588 & 3391 & 3978.088 & 0.512776 & 20.809 & 2578026297 & 1364876220 \\
\hline 2011 & 10453 & 2168 & 28000 & 4576 & 4201.268 & 0.807169 & 21.617 & 2942546781 & 1606438273 \\
\hline 2012 & 11425 & 3557 & 30000 & 6748 & 4018.407 & 0.932741 & 20.433 & 3801862611 & 1923442767 \\
\hline
\end{tabular}


Journal of Economics and Behavioral Studies (ISSN: 2220-6140)

Vol. 12, No. 2, pp. 34-56, April 2020

\begin{tabular}{llllllllll}
\hline 2013 & 9039 & 2927 & 19574 & 5622 & 3853.778 & 0.874528 & 17.521 & 4920343195 & 2360943478 \\
2014 & 9615 & 1442 & 26888 & 2816 & 3907.997 & 0.831858 & 20.398 & 5015157816 & 2597477049 \\
2015 & 4244 & 3243 & 12132 & 5982 & 4118.322 & 0.668026 & 24.153 & 4218723875 & 2474361443 \\
2016 & 11707 & 1545 & 31942 & 2352 & 4656.052 & 0.820682 & 26.374 & 3556036535 & 2069924108 \\
. &. &. &. &. & &. &. & 3775047334 & 2275732360 \\
\hline
\end{tabular}

